\title{
Century-Scale Responses of Ecosystem Carbon Storage and Flux to Multiple Environmental Changes in the Southern United States
}

\author{
Hanqin Tian, ${ }^{1,2 *}$ Guangsheng Chen, ${ }^{1,2}$ Chi Zhang, ${ }^{1,2}$ Mingliang Liu, ${ }^{1,2} \mathrm{Ge}$ \\ Sun, ${ }^{3}$ Arthur Chappelka, ${ }^{1,2}$ Wei Ren, ${ }^{1,2}$ Xiaofeng Xu, ${ }^{1,2}$ Chaoqun Lu, ${ }^{1,2}$ \\ Shufen Pan ${ }^{1,2}$ Hua Chen, ${ }^{4}$ Dafeng Hui, ${ }^{5}$ Steven McNulty, ${ }^{3}$ Graeme \\ Lockaby, ${ }^{1,2}$ and Eric Vance ${ }^{6}$
}

\begin{abstract}
${ }^{1}$ School of Forestry and Wildlife Sciences, Auburn University, 602 Duncan Drive, Auburn, Alabama 36849, USA; ${ }^{2}$ International Center for Climate and Global Change Research, Auburn University, Auburn, Alabama 36830, USA; ${ }^{3}$ Eastern Forest Environmental Threat Assessment Center, USDA Forest Service, Raleigh, North Carolina 27606, USA; ${ }^{4}$ State Key Laboratory of Desert and Oasis Ecology, Xinjiang Institute of Ecology and Geography, Chinese Academy of Sciences, Urumqi 830011, Xinjiang, China; ${ }^{5}$ Department of Biological Sciences, Tennessee State University, 3500 John A. Merritt Blvd, Nashville, Tennessee 37209, USA; ${ }^{6}$ National Council for Air and Stream Improvement (NCASI), Research Triangle Park, P.O. Box 13318, Raleigh, North Carolina 27709, USA
\end{abstract}

\begin{abstract}
Terrestrial ecosystems in the southern United States (SUS) have experienced a complex set of changes in climate, atmospheric $\mathrm{CO}_{2}$ concentration, tropospheric ozone $\left(\mathrm{O}_{3}\right)$, nitrogen $(\mathrm{N})$ deposition, and land-use and land-cover change (LULCC) during the past century. Although each of these factors has received attention for its alterations on ecosystem carbon (C) dynamics, their combined effects and relative contributions are still not well understood. By using the Dynamic Land Ecosystem Model (DLEM) in combination with spatially explicit, longterm historical data series on multiple environmental factors, we examined the century-scale responses of ecosystem C storage and flux to multiple environmental changes in the SUS. The results indicated that multiple environmental changes
\end{abstract}

Received 31 August 2011; accepted 24 February 2012; published online 20 April 2012

Author Contributions: H. Tian, A. Chappelka, S. Pan, G. Sun, S. McNulty, G. Lockaby and E. Vance designed the study; G. Chen, C. Zhang, M. Liu, W. Ren, X. Xu, C. Lu, H. Chen, D. Hui performed research; H.Tian, G. Chen and C. Zhang wrote the manuscript and all others contributed ideas to manuscript development.

*Corresponding author; e-mail: tianhan@auburn.edu shifted SUS ecosystems from a $\mathrm{C}$ source of $1.20 \pm 0.56 \mathrm{Pg}\left(1 \mathrm{Pg}=10^{15} \mathrm{~g}\right)$ during the period 1895 to 1950 , to a C sink of $2.00 \pm 0.94$ Pg during the period 1951 to 2007 . Over the entire period spanning 1895-2007, SUS ecosystems were a net C sink of $0.80 \pm 0.38 \mathrm{Pg}$. The $\mathrm{C}$ sink was primarily due to an increase in the vegetation $C$ pool, whereas the soil $C$ pool decreased during the study period. The spatiotemporal changes of $C$ storage were caused by changes in multiple environmental factors. Among the five factors examined (climate, LULCC, N deposition, atmospheric $\mathrm{CO}_{2}$, and tropospheric $\mathrm{O}_{3}$ ), elevated atmospheric $\mathrm{CO}_{2}$ concentration was the largest contributor to $\mathrm{C}$ sequestration, followed by $\mathrm{N}$ deposition. LULCC, climate, and tropospheric $\mathrm{O}_{3}$ concentration contributed to $\mathrm{C}$ losses during the study period. The SUS ecosystem C sink was largely the result of interactive effects among multiple environmental factors, particularly atmospheric $\mathrm{N}$ input and atmospheric $\mathrm{CO}_{2}$

Key words: climate change; carbon storage and flux; land use change; Dynamic Land Ecosystem Model (DLEM); southern United States. 


\section{INTRODUCTION}

The southern United States (SUS) is defined as the 13 states from the Mid-Atlantic coast west to Texas and Oklahoma, representing approximately $24 \%$ of the total land area, $25 \%$ of agricultural land, and $60 \%$ of forest land in the continental US (Wear 2002; Chen and others 2006). This region has experienced complex changes in multiple environmental factors, such as climate change, air pollution, and land-use and land-cover change (LULCC) during the past 300 years (Houghton and others 1999; Wear 2002; Karl and others 2009; Tian and others 2010a). Although recent studies suggest that this region is the largest carbon (C) sink among the six major bioclimatic regions in the US and has the greatest potential to be a significant C sink in the future (Schimel and others 2000; Birdsey and others 2006; Malmsheimer and others 2008), mechanisms underlying estimates of the long-term $\mathrm{C}$ balance of this region are still not well understood.

Changes in climate have been linked to both increases and decreases in plant growth and C storage in terrestrial ecosystems. For instance, large-scale droughts have reduced regional net primary productivity and C storage (Zhao and Running 2010; Chen and others 2012). Continued regional warming may result in $\mathrm{C}$ loss from ecosystems through enhanced plant and soil respiration (Woodwell and others 1995; Chen and Tian 2005), but increased nitrogen (N) availability has also been associated with increased plant growth (Tian and others 1999; Melillo and others 2002) and a lengthening of the active growing season (Myneni and others 1997). Elevated atmospheric $\mathrm{CO}_{2}$ and $\mathrm{N}$ deposition have been shown to stimulate photosynthesis in a variety of plant species and ecosystems (Curtis and Wang 1998; Ellsworth 1999; Norby and others 2005; Luo and others 2008). However, it is not clear how long the $\mathrm{CO}_{2}$ fertilization effects will last in cases where $\mathrm{N}$ or other nutrients become limiting (Oren and others 2001; Luo and others 2004; Johnson 2006). LULCC can influence ecosystem $\mathrm{C}$ dynamics in several ways including the direct impacts of biomass removal, for example, burning (Houghton and others 1999; Casperson and others 2000); changes in land management practices (for example, fertilization or irrigation) (Ollinger and others 2002); and indirect legacies such as litter decay, disruption of nutrient and water cycles, and wood product decay on the ecosystem structure (for example, species composition and biodiversity) and function (for example, plant regrowth, $\mathrm{N}$ and water cycles) as reported by
Ramankutty and others (2007). The impacts of tropospheric ozone $\left(\mathrm{O}_{3}\right)$ concentration on regional $\mathrm{C}$ dynamics have received less attention but current studies indicate that elevated $\mathrm{O}_{3}$ concentration has significantly reduced $\mathrm{C}$ sequestration and net primary productivity (NPP) of terrestrial plants, particularly agricultural crops, which could offset the positive effects of elevated atmospheric $\mathrm{CO}_{2}$ and $\mathrm{N}$ deposition (Chameides and others 1994; Chapelka and Samulson 1998; Ollinger and others 2002; Felzer and others 2004; Ren and others 2007a, $2011 \mathrm{a}, \mathrm{b})$.

Although site-level research has provided valuable insights into the ecological impacts of individual environmental factors, the magnitude and spatial patterns of these factors and their interactions with regional $\mathrm{C}$ dynamics are not well understood in the SUS. Simple extrapolations based on contemporary datasets (for example, Houghton and others 1999; Han and others 2007) may not be robust since the spatial-temporal heterogeneity of environmental constraints, interactions among multiple factors, and longterm legacy effects are ignored. Most previous studies in this region have focused only on individual or a small subset of environmental controls over a short period (for example, Houghton and others 1999; Schimel and others 2000; Chen and others 2006). Both theoretical research and field experiments have revealed that ecosystem responses to environmental changes are not necessarily additive and could have complex, interactive effects on ecosystem structure and functioning (Oren and others 2001; Ollinger and others 2002; Luo and others 2008; Tian and others $201 \mathrm{la}$, b). Zhou and others (2008) and McNulty and Boggs (2010) have also suggested that ecosystem responses to multifactor environmental changes could be controlled by complex $\mathrm{C}, \mathrm{N}$, and water cycling processes.

We applied a process-based ecosystem model (Dynamic Land Ecosystem Model, DLEM), which fully couples $\mathrm{C}, \mathrm{N}$, and water cycles (Tian and others 2010a, 201la, b) to assess the impacts of multiple environmental factors (for example, climate, atmospheric $\mathrm{CO}_{2}$, tropospheric $\mathrm{O}_{3}, \mathrm{~N}$ deposition, and LULCC) and their contributions to $\mathrm{C}$ fluxes in the SUS. The two objectives of this study are to quantify the magnitude and spatial-temporal patterns of $C$ storage and fluxes, and estimate relative contributions of multiple environmental factors to long-term terrestrial $\mathrm{C}$ fluxes in the SUS using long-term, spatially explicit environmental data and model simulations. 


\section{MeTHODS}

\section{Study Region}

The SUS extends roughly from $75^{\circ}$ to $100^{\circ}$ west longitude and from $30^{\circ}$ to $37^{\circ}$ north latitude, including 13 states: Alabama, Arkansas, Florida, Georgia, Kentucky, Louisiana, Mississippi, North Carolina, Oklahoma, South Carolina, Virginia, Tennessee, and Texas (Figure 1). Elevations within the region range from sea level along the Gulf of Mexico and Atlantic coasts to more than $1,800 \mathrm{~m}$ in the Appalachian Mountains. Overall, the climate is temperate, becoming largely subtropical near the coast. The dominant forest types in this region are temperate evergreen needleleaf and deciduous broadleaf.

\section{Model Description, Parameterization, and Corroboration}

The DLEM is a process-based terrestrial ecosystem model that simulates daily $\mathrm{C}, \mathrm{N}$, and water cycles as influenced by changes in atmospheric chemistry $\left(\mathrm{O}_{3}, \mathrm{CO}_{2}\right.$, and $\mathrm{N}$ deposition), climate, LULCC, and disturbances (for example, fire, hurricane, and harvest). The DLEM couples multiple processes and their interactions through five core components (Figure 2): (1) biophysics, (2) plant physiology, (3) soil biogeochemistry, (4) dynamic vegetation, and (5) disturbance, land-use and management. The biophysical component includes instantaneous exchanges of energy, water, and momentum with the atmosphere. Micrometeorology, canopy physiology, soil physics, radiative transfer, and water and energy flow are represented by the model. The DLEM simulates major physiological processes such as photosynthesis, respiration, and carbohydrate allocation among various parts (root, stem, and leaf), as well as processes such as $\mathrm{N}$ uptake and transpiration. Mineralization, nitrification, denitrification, aerobic and anaerobic decomposition are simulated in the soil component so that the DLEM is able to estimate simultaneous emissions of multiple trace gases $\left(\mathrm{CO}_{2}, \mathrm{CH}_{4}\right.$, and $\left.\mathrm{N}_{2} \mathrm{O}\right)$. The DLEM has also been used to quantify water, $\mathrm{C}$, and $\mathrm{N}$ cycles in managed ecosystems, including cropland, forest plantations, and pasture. Detailed information on how these ecosystem processes are modeled can be found in Tian and others (2010a).

The uptake of atmospheric $\mathrm{CO}_{2}$ by vegetation during photosynthesis is represented by gross primary production (GPP) in the DLEM. Carbon dioxide is returned to the atmosphere from the autotrophic respiration of plants $\left(R_{\mathrm{A}}\right)$ and through heterotrophic respiration $\left(R_{\mathrm{H}}\right)$ associated with decomposition. Net primary production (NPP) is calculated as the difference between GPP and $R_{\mathrm{A}}$. The net $\mathrm{C}$ exchange (NCE) of $\mathrm{CO}_{2}$ between the terrestrial biosphere and the atmosphere from natural ecosystem metabolism is represented by net ecosystem production (NEP), which is calculated as

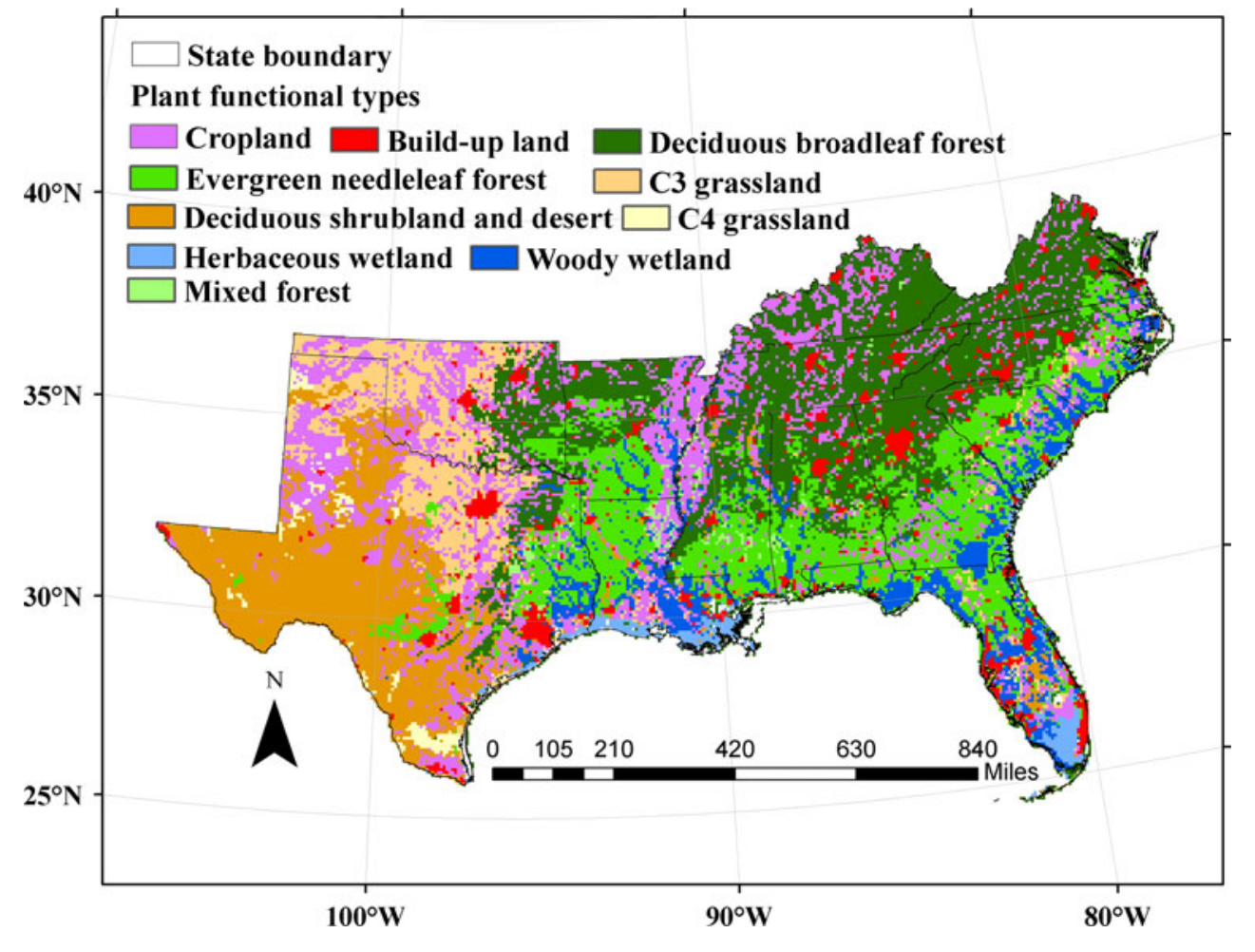

Figure 1. The state boundaries and major plant functional types in the SUS. 
Regional Climate and Atmosphere Chemistry temperature, precipitation, radiation, wind, pressure, humidity; $\mathrm{CO}_{2}, \mathrm{Ozone}, \mathrm{NO}_{\mathrm{y}}, \mathrm{NH}_{x}$

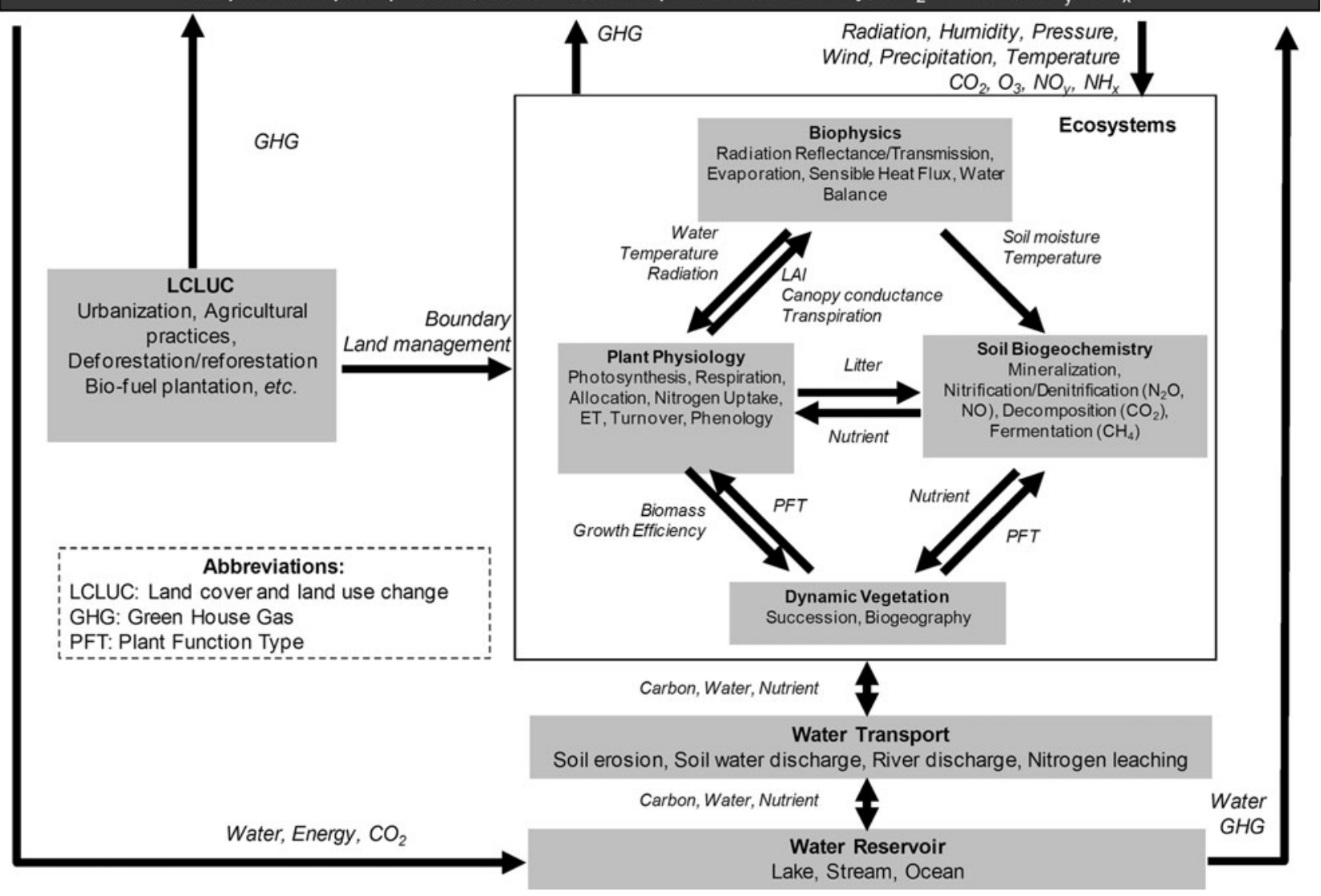

Figure 2. The schematic framework of the DLEM (Dynamic Land Ecosystem Model).

the difference between NPP and $R_{\mathrm{H}}$. The DLEM also accounts for the $\mathrm{C}$ fluxes during land conversion among different plant functional types and the sum of $C$ emissions $\left(E_{\mathrm{C}}\right)$ from decay of agricultural and wood products $\left(E_{\mathrm{P}}\right)$. In addition, $\mathrm{CH}_{4}$ emissions $\left(E_{\mathrm{CH}_{4}}\right)$ are deducted from the $\mathrm{C}$ fluxes. Thus, the NCE is calculated as follows: NCE $=$ GPP $-R_{\mathrm{A}}-$ $R_{\mathrm{H}}-E_{\mathrm{C}}-E_{\mathrm{P}}-E_{\mathrm{CH}_{4}}=\mathrm{NEP}-E_{\mathrm{C}}-E_{\mathrm{P}}-E_{\mathrm{CH}_{4}}$. A positive value of NCE represents a gain of $C$ in terrestrial ecosystems, whereas a negative value represents a loss.

Model parameterization for the SUS has been described in detail in Tian and others (2010a). The DLEM has been corroborated for $\mathrm{C}$ and water fluxes (Tian and others 2010a, $2011 \mathrm{la}$, b; Liu and others 2008, 2012; Richardson and others 2012; Sulman and others 2012; Huntzinger and others 2012), N storage and fluxes (Lu and others 2012; Tian and others 2010b), and soil $\mathrm{C}$ and $\mathrm{N}$ transformation processes and trace greenhouse gas emissions (Tian and others 2010b, 2011a; Xu and others 2010). Zhang and others (2010) also corroborated the simulated forest vegetation, litter, coarse woody debris (CWD), and total (vegetation + soil + litter + CWD) C stocks for each SUS state against corresponding observational data from USDA Forest Service Forest Inventory and Analysis (FIA) collected from 1987 to 1997 (Data source: Birdsey and Lewis 2003). The regression between simulated and observed total C stocks in 1997 shows that DLEM was able to accurately simulate total C stocks across the SUS (Figure 3A; $P<0.01 ; R^{2}=0.73$; slope $=$ 1.13; coefficient of variation of root mean square deviation, $C V(R M S D)=0.094)$. In addition, four major vegetation types were selected to corroborate DLEM-simulated daily NEP patterns in this study (Figure 3B-E). Compared to observations, the DLEM-simulated NEP tended to be more biased at extreme high or low values. However, the model generally captured the daily patterns for evergreen needleleaf forest (US-Dk3; $R^{2}=0.30 ; \mathrm{CV}(\mathrm{RMSD})=$ 1.59; $n=2920$ ), deciduous broadleaf forest (US$\left.\mathrm{Dk} 2 ; R^{2}=0.60 ; \mathrm{CV}(\mathrm{RMSD})=1.22 ; n=1825\right), \mathrm{C}_{3}$ grassland (US-Shd; $R^{2}=0.54 ; \mathrm{CV}(\mathrm{RMSD})=1.24$; 

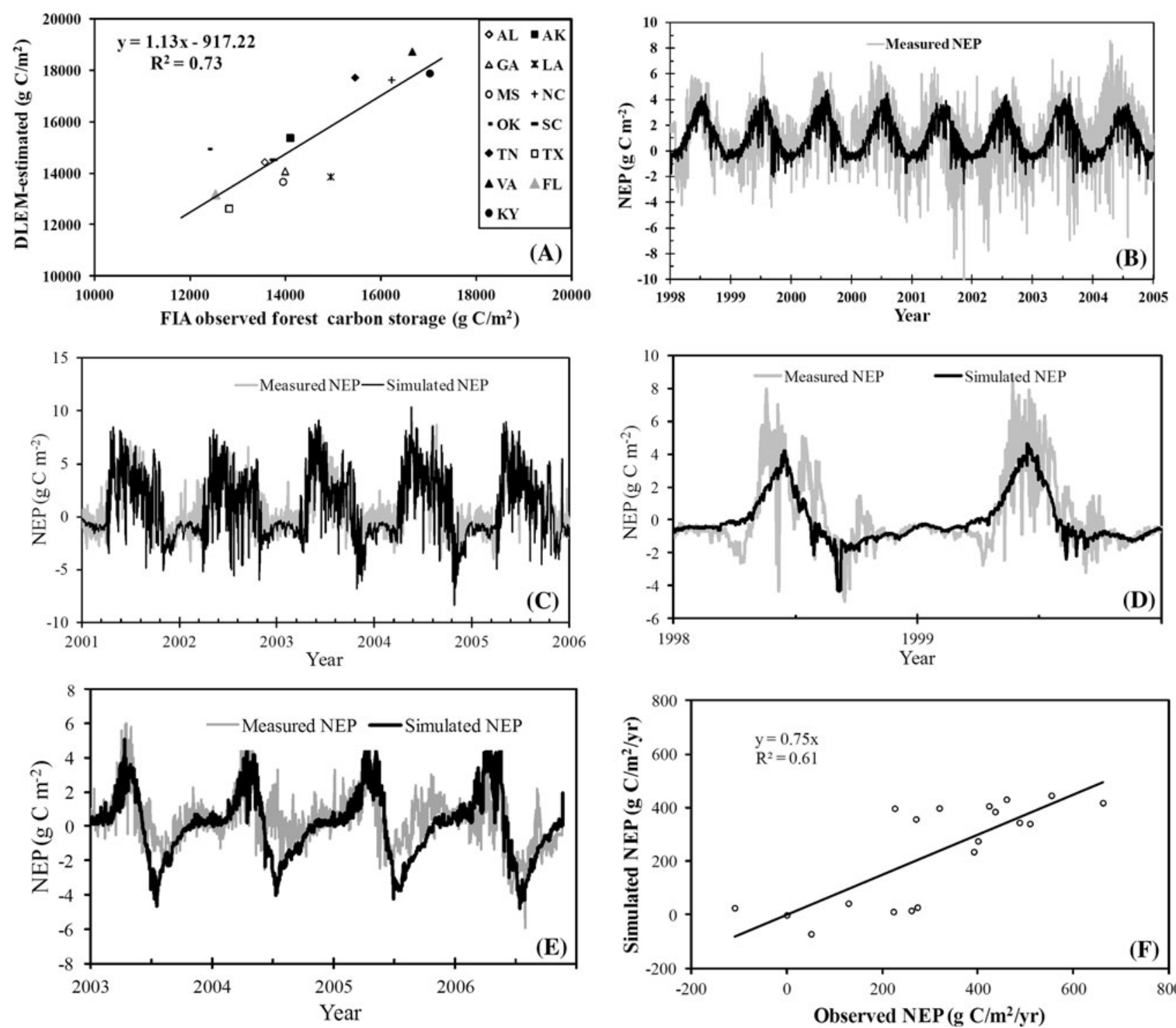

Figure 3. Comparisons of simulated and observed C storage and net ecosystem production (NEP) for different states and land-cover types in the SUS. A Correlation between simulated and FIA-observed total ecosystem C storage in different states; B Simulated and observed NEP for US-Dk3 AmeriFlux site (Evergreen needleleaf forest); C For US-Dk2 AmeriFlux site (Deciduous broadleaf forest); D For US-Shd AmeriFlux site $\left(\mathrm{C}_{3}\right.$ grassland); E For US-ARM AmeriFlux site (Cropland); F Correlation between simulated and observed annual $\mathrm{C}$ fluxes in the four selected AmeriFlux sites.

$n=730$ ), and cropland (US-ARM; $R^{2}=0.44$; $\mathrm{CV}(\mathrm{RMSD})=1.39 ; n=1419)$. At an annual scale, we found a higher correlation and less RMSE between simulated and observed $\operatorname{NEP}\left(R^{2}=0.61\right.$; slope $=0.75 ; \mathrm{CV}(\mathrm{RMSD})=0.47)$ for all these sites (Figure $3 \mathrm{~F}$ ), indicating that the model was better able to capture interannual rather than daily variation.

\section{Input Data Description}

The model input data included historical LULCC, climate, atmospheric $\mathrm{CO}_{2}$, tropospheric $\mathrm{O}_{3}$ con- centrations, and $\mathrm{N}$ deposition (Table 1). The geospatial data were converted to the same spatial scale $(8 \mathrm{~km} \times 8 \mathrm{~km})$. A detailed description of sources and the development of input datasets can be found in Chen and others (2006); Zhang and others (2012), and Tian and others (2010a).

Air temperature exhibited an increasing trend from 1895 to the mid-1950s $\left(0.12^{\circ} \mathrm{C}\right.$ per decade) and then showed a sudden decrease over several years (1955-1960) (Figure 4B). After the 1960s, air temperature increased again with time $\left(0.12^{\circ} \mathrm{C}\right.$ per decade). Therefore, during the entire study 
Table 1. Data Sources and Methods used to Generate the Input Data Sets for Model Simulation in this Study

\begin{tabular}{|c|c|c|c|}
\hline Input data & Unit & Temporal resolution & Methods and data sources \\
\hline Potential vegetation map & 8 categories & \multirow[t]{9}{*}{$\begin{array}{l}\text { Non-transient base } \\
\text { map }\end{array}$} & $\begin{array}{l}\text { Aggregated from the NLCD2001 land cover } \\
\text { dataset (Homer and others 2007). }\end{array}$ \\
\hline $\begin{array}{l}\text { Soil texture (clay, silt and } \\
\text { sand) }\end{array}$ & $\%$ & & \multirow{4}{*}{$\begin{array}{l}\text { Based on the } 1 \mathrm{~km} \text { resolution digital general soil } \\
\text { association map (STATSGO) that was devel- } \\
\text { oped by USDA Natural Resources Conserva- } \\
\text { tion (NRC), while soil texture was derived } \\
\text { from the USDA soil texture triangle (Miller } \\
\text { and White 1998) }\end{array}$} \\
\hline Soil depth & $\mathrm{m}$ & & \\
\hline Soil acidity & $\mathrm{pH}$ & & \\
\hline Soil bulk density & $\mathrm{g} / \mathrm{cm}^{3}$ & & \\
\hline Elevation map & $\mathrm{m}$ & & \multirow{3}{*}{$\begin{array}{l}\text { Generated from the } 7.5 \text { minute USGS National } \\
\text { Elevation Dataset (NED). Data available on- } \\
\text { line: http://edcnts } 12 . \mathrm{cr} . \text { usgs.gov/ned/ } \\
\text { ned.html }\end{array}$} \\
\hline Aspect map & $\circ$ & & \\
\hline Slope map & $\circ$ & & \\
\hline Irrigation map & $1 / 0$ & & $\begin{array}{l}\text { From an Irrigated Area Map of the World } \\
\text { developed by Thenkabail and others }(2006)\end{array}$ \\
\hline Precipitation & $\mathrm{mm}$ & \multirow[t]{5}{*}{ Daily } & \multirow{4}{*}{$\begin{array}{l}\text { Developed by integrating the daily climate pat- } \\
\text { tern from the North American Regional } \\
\text { Reanalysis dataset (Mesinger and others } \\
\text { (2006); www.emc.ncep. noaa.gov), and the } \\
\text { monthly climate dataset developed by the } \\
\text { Parameter-elevation Regressions on Inde- } \\
\text { pendent Slopes Model (PRISM) (http://pris- } \\
\text { m.oregonstate.edu/) }\end{array}$} \\
\hline Maximum temperature & ${ }^{\circ} \mathrm{C}$ & & \\
\hline Minimum temperature & ${ }^{\circ} \mathrm{C}$ & & \\
\hline Average temperature & ${ }^{\circ} \mathrm{C}$ & & \\
\hline Ozone index AOT40 ${ }^{1}$ & ppb h & & Dataset developed by Felzer and others (2004) \\
\hline $\mathrm{CO}_{2}$ & ppmv & \multirow[t]{6}{*}{ Annual } & $\begin{array}{l}\text { IPCC } \mathrm{CO}_{2} \text { concentration data (Enting and others } \\
1994\end{array}$ \\
\hline Nitrogen deposition ${ }^{2}\left(\mathrm{NH}_{x}\right)$ & $\mathrm{g} \mathrm{N} / \mathrm{m}^{2} / \mathrm{y}$ & & \multirow[b]{2}{*}{$\begin{array}{l}\text { Developed based on the global N deposition } \\
\text { datasets of three periods }(1860,1993 \text {, and } \\
\text { 2050) generated by Dentener }(2006) \text {. Annua } \\
\text { variations were controlled by the global his- } \\
\text { torical N emission dataset developed by Van } \\
\text { Aardenne and others (2001) }\end{array}$} \\
\hline Nitrogen deposition $\left(\mathrm{NO}_{y}\right)$ & $\mathrm{g} \mathrm{N} / \mathrm{m}^{2} / \mathrm{y}$ & & \\
\hline Cropland fertilization & $\mathrm{g} \mathrm{N} / \mathrm{m}^{2} / \mathrm{y}$ & & $\begin{array}{l}\text { Based on the county-level fertilizer consump- } \\
\text { tion records (Alexander and Smith 1990; } \\
\text { Ruddy and others } 2006\end{array}$ \\
\hline Cropland conversion & $0 / 1$ & & \multirow{2}{*}{$\begin{array}{l}\text { Value } 1 \text { means urban or cropland. Developed } \\
\text { with approaches described by Chen and oth- } \\
\text { ers }(2006)\end{array}$} \\
\hline Urbanization & $0 / 1$ & & \\
\hline
\end{tabular}

${ }^{1}$ AOT4O $(\mathrm{ppb} h)$ is the accumulated dose over a threshold of $40 \mathrm{ppb}$ during daylight hours.

${ }^{2} \mathrm{~N}$ deposition include $\mathrm{NH}_{x}\left(\mathrm{NH}_{3}\right.$ and $\left.\mathrm{NH}_{4}^{+}\right)$, and $\mathrm{NO}_{y}$ (all oxidized forms of $\mathrm{N}$ other than $\mathrm{N}_{2} \mathrm{O}$ ).

period, there was no obvious trend in air temperature across the SUS. Annual precipitation ranged from $797 \mathrm{~mm}$ in 1954 to $1,316 \mathrm{~mm}$ in 1973 with huge interannual variability (Figure $4 \mathrm{~A}$ ). The study region experienced significant droughts during the mid-1950s (from 1952 to 1956) and again from 2005 to 2007. Annual mean precipitation in the SUS decreased along an eastwest gradient with a semiarid climate in the west and a humid climate in the east. Although precipitation showed a general increasing trend for the entire SUS, precipitation decreased in parts of the eastern portion of the SUS from 1895 to 2007
(Tian and others 2010a). The highest precipitation $(>2,000 \mathrm{~mm} / \mathrm{y})$ was found in the Great Smoky Mountains region and the lowest in the northwestern Texas $(<200 \mathrm{~mm} / \mathrm{y})$.

The rate of $\mathrm{N}$ deposition, $\mathrm{N}$ fertilizer use in croplands, and tropospheric $\mathrm{O}_{3}$ concentrations (AOT40) increased dramatically from the 1950s to the 1970s (Figure 4C, D, F). The increasing trend of $\mathrm{N}$ deposition slowed down after 1980 but continued to increase (Figure 4C). Fertilizer $\mathrm{N}$ use for cropland reached its peak in 1994 and leveled off thereafter (Figure 4D). After increasing initially, tropospheric $\mathrm{O}_{3}$ remained relatively stable after 

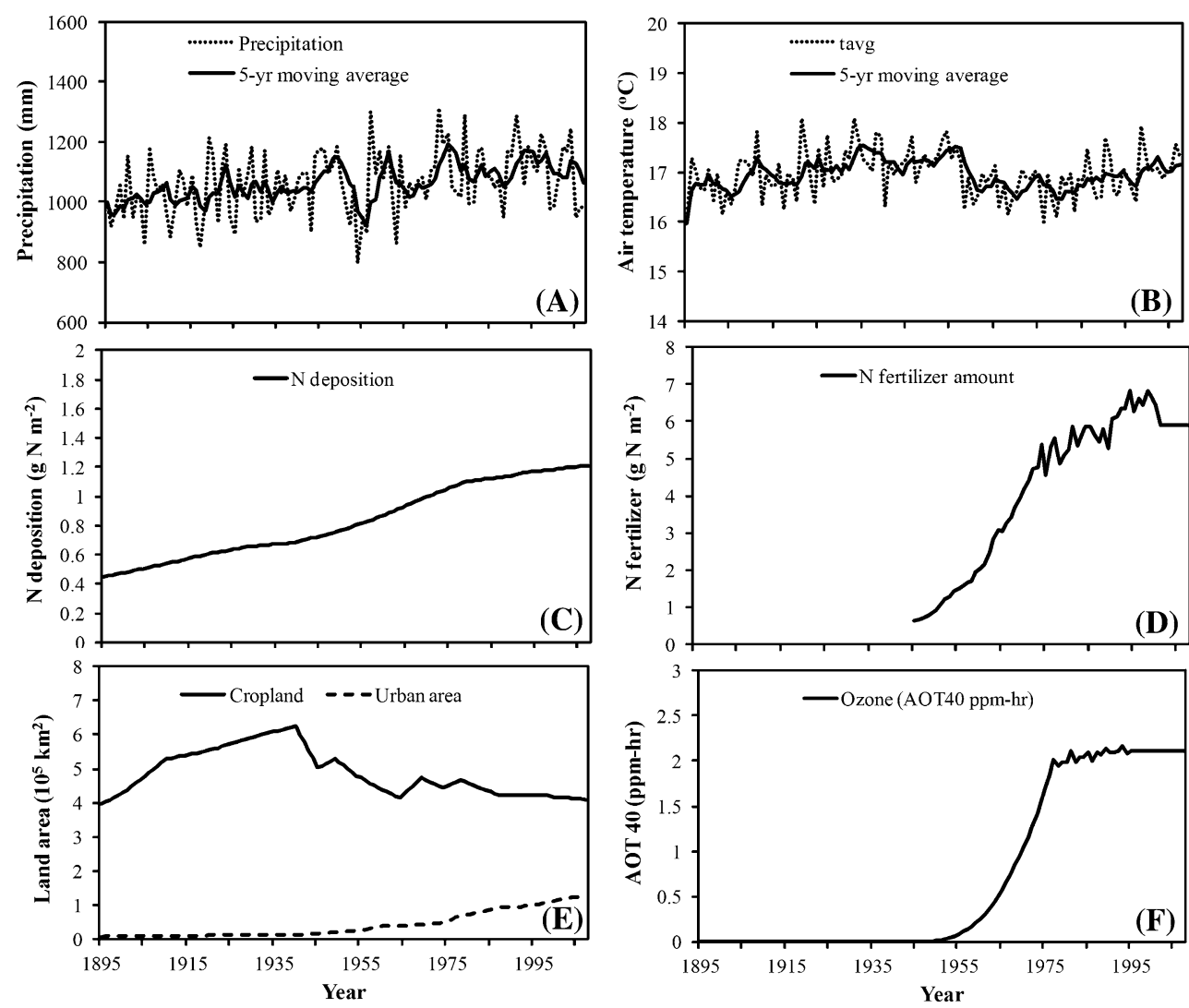

Figure 4. Annual

variations of

environmental factors in

the SUS from 1895 to

2007. A Mean annual

precipitation $(\mathrm{mm})$; $\mathbf{B}$

Mean annual

temperature $\left({ }^{\circ} \mathrm{C}\right) ; \mathbf{C ~ N}$

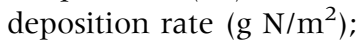

D $\mathrm{N}$ fertilizer amounts in the cropland $\left(\mathrm{g} \mathrm{N} / \mathrm{m}^{2}\right)$; $\mathbf{E}$ Interannual changes in cropland and urban area from 1895 to $2007\left(10^{5}\right.$ $\mathrm{km}^{2}$ ); $\mathbf{F}$ mean exposure to tropospheric ozone stress as measured by AOT40 index (AOT40: hourly accumulated daytime dose over $40 \mathrm{ppm}$ during a month, ppm h).

1980 (Figure 4F). The eastern portion of the study region (that is, Virginia, Kentucky, Tennessee, and North Carolina) received much higher rates of $\mathrm{N}$ deposition and $\mathrm{O}_{3}$ concentrations than the other areas in the study region (Figure 5C-E). The total N deposition rate in Kentucky and the eastern Virginia was as high as $2.0 \mathrm{~g} \mathrm{~N} / \mathrm{m}^{2} / \mathrm{y}$.

The temporal pattern of LULCC was quite complex during the study period (Figure 4E). Before the 1940s, the LULCC was dominated by land conversion from natural vegetation to cropland. Cropland area expanded from 39 million ha to 62 million ha from 1895 to 1940 , resulting in decreases in forest $(7 \%)$, shrubland $(13 \%)$, and grassland $(32 \%)$ area over this time period. After 1940, LULCC was characterized as land conversion from cropland to natural vegetation due to cropland abandonment and afforestation/reforestation. The area of forest increased by about $13 \%$ from 1940 to the end of 1960s. After the 1960s, cropland area decreased by $13 \%$ due primarily to urban area expansion, which doubled from 1980 to 2007. Cropland abandonment primarily resulted in reforestation or afforestation in the southeast portion of the region (for example, Virginia, Georgia) where forests are the dominant native ecosystem type, and in conversion to grassland or shrubland in the southcentral areas of the SUS (for example, Texas, Oklahoma) (Figure 5G).

\section{Model Simulation and Experimental Designs}

The model simulation encompassed the entire SUS from 1895 to 2007 with a spatial resolution of $8 \mathrm{~km} \times 8 \mathrm{~km}$. DLEM was first run to an equilibrium state using mean climate datasets to develop the simulation baseline for $\mathrm{C}, \mathrm{N}$, and water pools. Then a 90-year spin-up simulation was conducted using the detrended climate data to eliminate noise caused by simulation shift from the equilibrium to transient mode. The data-detrending approach subtracts the best-fit line from transient climate dataset, and only retains the fluctuations about the trend. Such a dataset is required for stabilizing the simulation before entering the transient mode. Finally, the DLEM simulated daily $\mathrm{C}$ fluxes and pool sizes at $8 \mathrm{~km} \times 8 \mathrm{~km}$ spatial resolution using the daily transient datasets from 1895 to 2007 .

In this study, 16 model simulations were designed to investigate impacts of individual environmental stresses and their interactions on the ecosystem C dynamics in the SUS. There were three types of simulations. The first type was a 


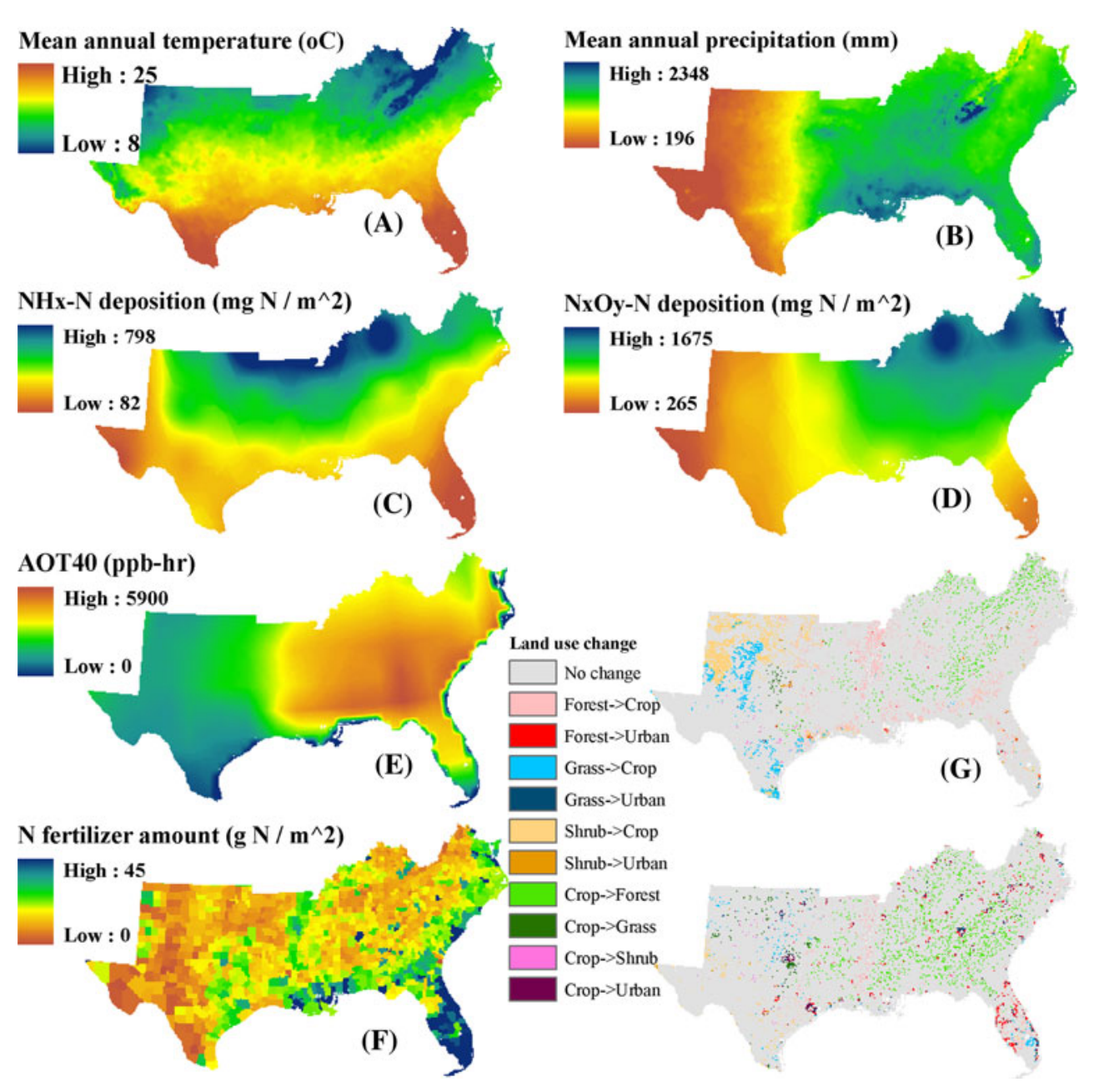

Figure 5. Spatial patterns of multiple environmental change factors in the SUS. (A, B) daily temperature and annual precipitation from 1895 to 2007

respectively; C, D annual $\mathrm{N}$ deposition rates in 2007 (mg N/m ${ }^{2}$. $\mathrm{NH}_{x}$ includes $\mathrm{NH}_{3}$ and $\mathrm{NH}_{4}{ }^{+} ; \mathrm{N}_{x} \mathrm{O}_{y}$ includes oxidized forms of $\mathrm{N}$ other than $\mathrm{N}_{2} \mathrm{O}$ ); $\mathbf{E}$ mean exposure to tropospheric ozone stress as measured by AOT40 index (ppb h) in 1990s; F county-level $\mathrm{N}$ fertilizer amounts in cropland in $2000\left(\mathrm{~g} \mathrm{~N}^{2} \mathrm{~m}^{2}\right)$; G LULCC from 1895 to 1951 and from 1951 to 2007.

single factor simulation (five separate simulations) used to reveal effects of individual environmental factors on the $\mathrm{C}$ dynamics. The simulations were (1) CLM: climate change only; (2) $\mathrm{CO}_{2}: \mathrm{CO}_{2}$ change only; (3) OZONE: $\mathrm{O}_{3}$ change only; (4) NDEP: N deposition change only; (5) LUC: LULCC only (including land management practices in cropland, such as irrigation and fertilization). The second type was the ALLCOMBINE simulation, which included all five environmental factors to reflect $\mathrm{C}$ dynamics in the "real world." The third type was comprised of ten simulations, for example, $\mathrm{CO}_{2}+\mathrm{NDEP}, \mathrm{CO}_{2}+\mathrm{CLM}, \mathrm{CLM}+\mathrm{LUC}$, and so on, developed to estimate the interaction of two individual factors on $\mathrm{C}$ fluxes and storage. The total interactive effect among multiple environmental factors was calculated as ALLCOMBINE - CLM NDEP - $\mathrm{CO}_{2}-$ OZONE - LUC, whereas the twofactor interactive effect was calculated as the combined effects of two factors minus that of each factor individually. For example, the interactive effect between CLM and $\mathrm{CO}_{2}$ was calculated as $\mathrm{CLMCO}_{2}-\mathrm{CLM}-\mathrm{CO}_{2}$.

\section{Statistical Analysis}

The Spearman's correlation was used to evaluate the consistency between observed and simulated interannual and daily patterns of NCE. Statistical significance $(P<0.05)$ of correlation coefficients and linear regression models was calculated using an $F$ test. CV(RMSD), which is defined as the RMSD normalized to the mean of the observed values, was used as one of the indices for evaluating model performance. In addition, the CV(RMSD) between observed and simulated C storage (for example, vegetation $\mathrm{C}$, soil $\mathrm{C}$, total $\mathrm{C}$ ) and flux (NCE) was used to estimate uncertainty for simulated regional $\mathrm{C}$ storage and flux.

\section{Results AND Analysis}

Temporal Changes in C Flux and Storage in the SUS

Simulated results indicated that multiple changes in climate, atmospheric composition, and land use and land cover resulted in a net $\mathrm{C}$ sink of 
$0.80 \pm 0.38 \mathrm{Pg}\left(1 \mathrm{Pg}=10^{15} \mathrm{~g}\right)$ in the SUS for the entire study period (that is, 1895 to 2007). This sink accounted for $2.7 \%$ of the total ecosystem C storage within the SUS in 1895 (Table 2). However, SUS terrestrial ecosystems were a $\mathrm{C}$ source of $1.20 \pm 0.56$ Pg from 1895 to 1950 and a C sink of $2.00 \pm 0.94 \mathrm{Pg}$ from 1951 to 2007 (Table 2; Figure 6A).
$C$ in vegetation changed more rapidly than did other C pools (that is, soil, product, and litter) during the study period. Vegetation $\mathrm{C}$ decreased by $5.0 \%$ from 1895 to 1950 and increased by $14.0 \%$ from 1951 to 2007 (Table 2). In comparison, soil organic $\mathrm{C}$ decreased by $4.0 \%$ for the first period and increased by $3.2 \%$ during the second period, respectively. Vegetation C shifted from a C source

Table 2. Changes in the Ecosystem C Storage in the SUS from 1895 to 2007

\begin{tabular}{|c|c|c|c|c|c|c|}
\hline & & \multicolumn{5}{|c|}{ Carbon pools } \\
\hline & & VEGC & SOC & LTRC & PRODC & ТОТС \\
\hline \multirow[t]{3}{*}{ Year } & 1895 & 8.53 & 19.40 & 1.42 & 0.02 & 29.37 \\
\hline & 1951 & 8.11 & 18.62 & 1.30 & 0.13 & 28.17 \\
\hline & 2007 & 9.24 & 19.23 & 1.47 & 0.22 & 30.17 \\
\hline \multirow{2}{*}{$1895-1951$} & Difference & -0.42 & -0.78 & -0.12 & 0.12 & -1.20 \\
\hline & Change rate $(\%)$ & -4.96 & -4.01 & -8.44 & 658 & -4.11 \\
\hline \multirow[t]{2}{*}{$1951-2007$} & Difference & 1.14 & 0.61 & 0.17 & 0.09 & 2.00 \\
\hline & Change rate $(\%)$ & 14.05 & 3.25 & 13.22 & 67.71 & 7.12 \\
\hline \multirow[t]{2}{*}{ 1895-2007 } & Difference & 0.72 & -0.17 & 0.05 & 0.21 & 0.80 \\
\hline & Change rate $(\%)$ & 8.38 & -0.90 & 3.66 & 1170 & 2.72 \\
\hline
\end{tabular}

VEGC: vegetation carbon; SOC: soil organic carbon; LTRC: litter carbon; PRODC: carbon in the harvested products (for example, crop yields, wood products); TOTC: the total carbon storage (including $0.21 \mathrm{Pg} \mathrm{C}$ emitted as $\mathrm{CH}_{4}$ ).

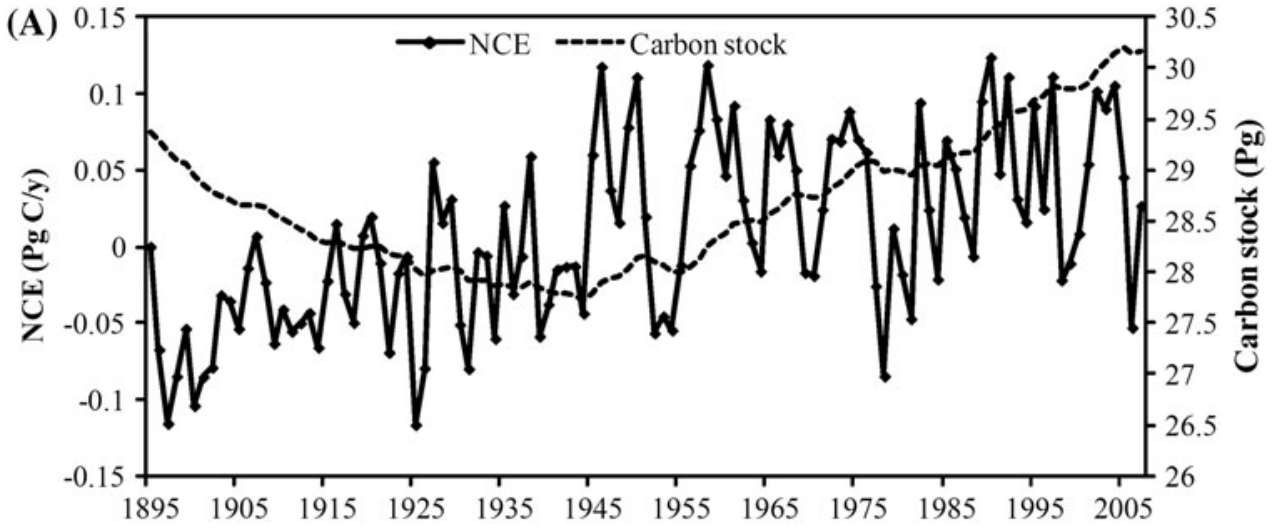

(B)

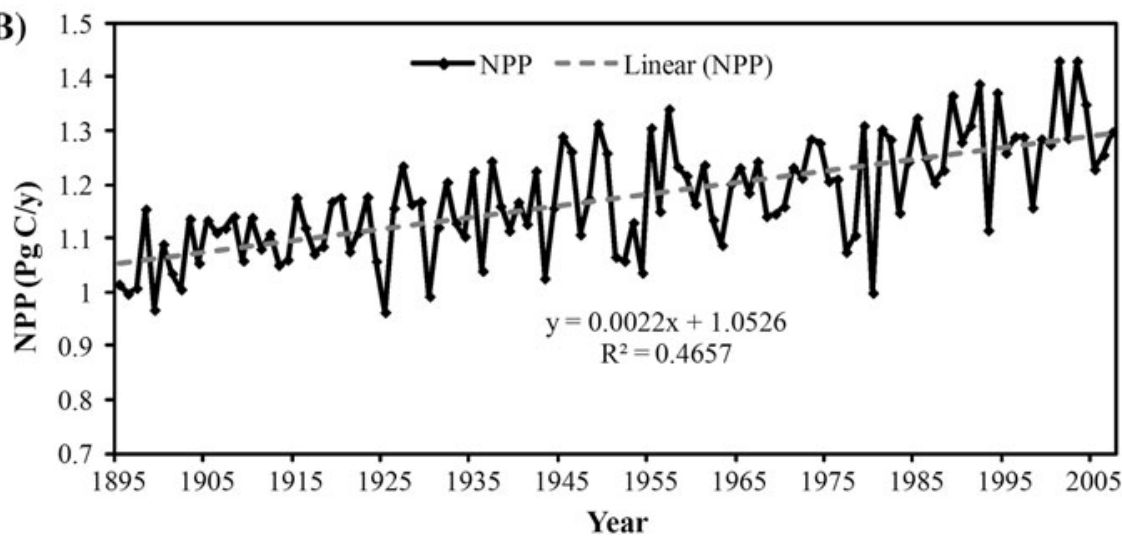

Figure 6. Simulated interannual variation in A C storage (including vegetation, soil, litter and product pools, $\mathrm{Pg} \mathrm{C}$ ) and NCE (Pg C/y), and B NPP $(\mathrm{Pg} / \mathrm{y})$ in the SUS from 1895 to 2007. $1 \mathrm{Pg}=10^{15} \mathrm{~g}$. 


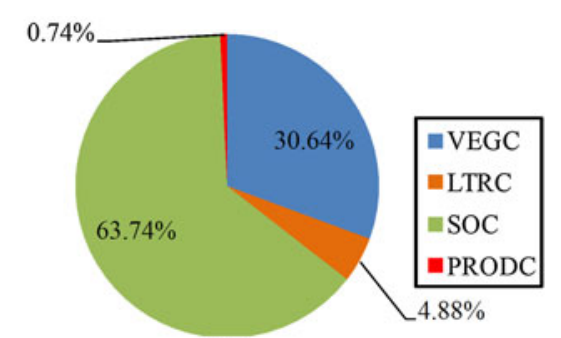

(A)

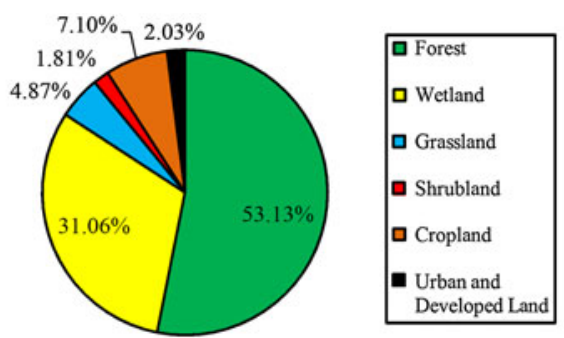

(B)
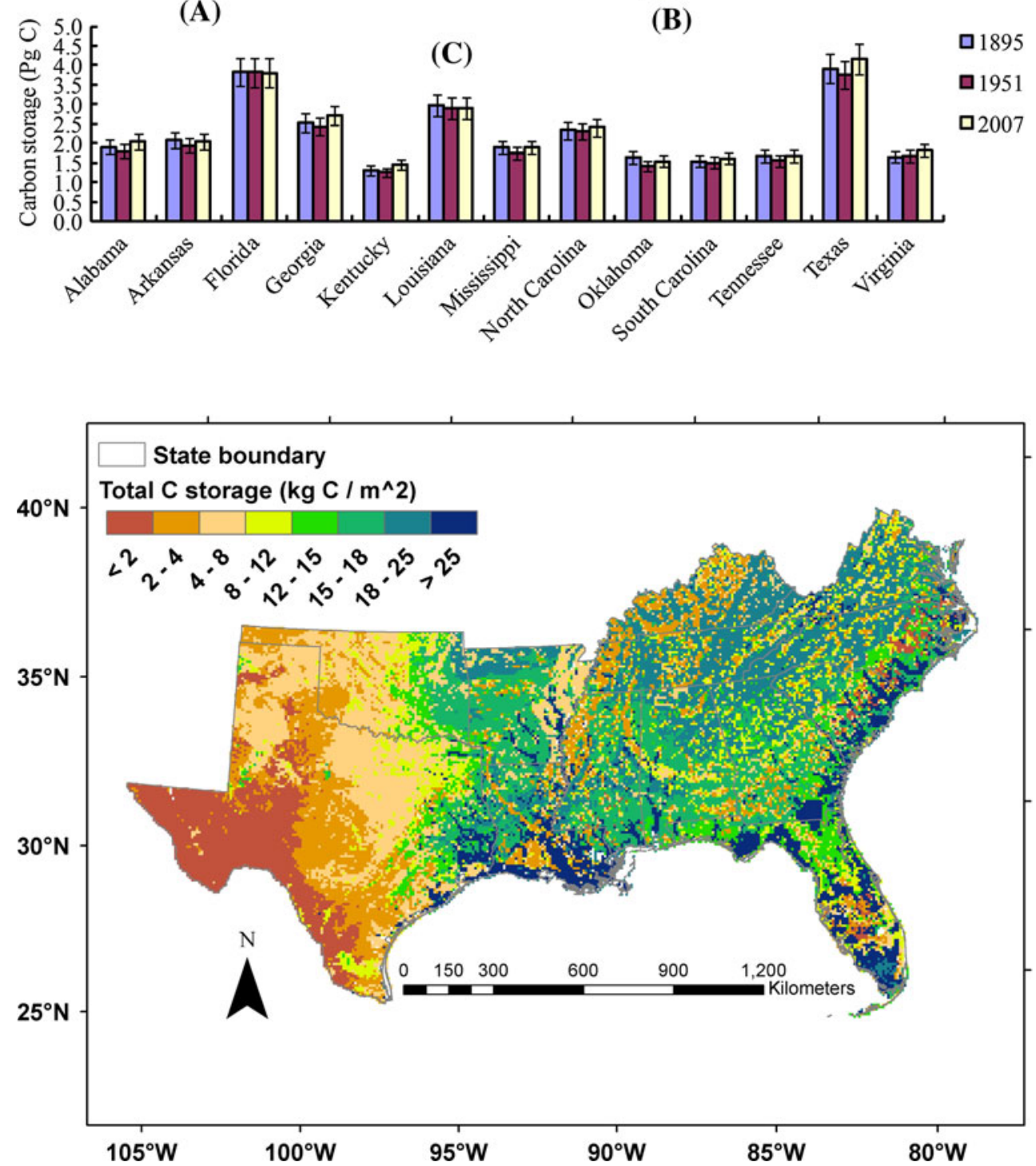

Figure 7. Distribution of C storage in different $\mathbf{A} \mathrm{C}$ pools in 2007, B land-use and land-cover types in 2007, and $\mathbf{C}$ states (in 1895, 1951, and 2007). VEGC vegetation carbon, LTRC litter carbon, SOC soil organic carbon, PRODC carbon in product pools.
Figure 8. Spatial distribution of $\mathrm{C}$ storage $\left(\mathrm{kg} \mathrm{C} / \mathrm{m}^{2}\right)$ in the SUS in 2007 as simulated by the DLEM. to a C sink in the mid-1940s, whereas soil C shifted to a C sink after the mid-1950s. The vegetation C pool was more responsive to environmental changes (for example, climate, $\mathrm{CO}_{2}$ concentration) than the soil $\mathrm{C}$ pool. Although the vegetation $\mathrm{C}$ pool size was only about $48 \%$ of the soil $C$ pool size (Figure 7A; Table 2), variations in the vegetation $\mathrm{C}$ pool accounted for a greater proportion of longterm change in C storage in the SUS. The net C sink of $0.80 \mathrm{Pg}$ during 1895 to 2007 resulted from combined $\mathrm{C}$ in vegetation, litter, and wood product pools $(0.97 \pm 0.09 \mathrm{Pg})$ being larger than $\mathrm{C}$ losses $(0.17 \pm 0.02 \mathrm{Pg})$ from soil pools.

\section{Spatial Variation in C Storage and Fluxes}

Land use, land-cover type, and precipitation were the primary determinants of $\mathrm{C}$ density, which increased from west to east (Figure 8). The highest $\mathrm{C}$ storage, generally greater than $25 \mathrm{~kg} / \mathrm{m}^{2}$, was in 


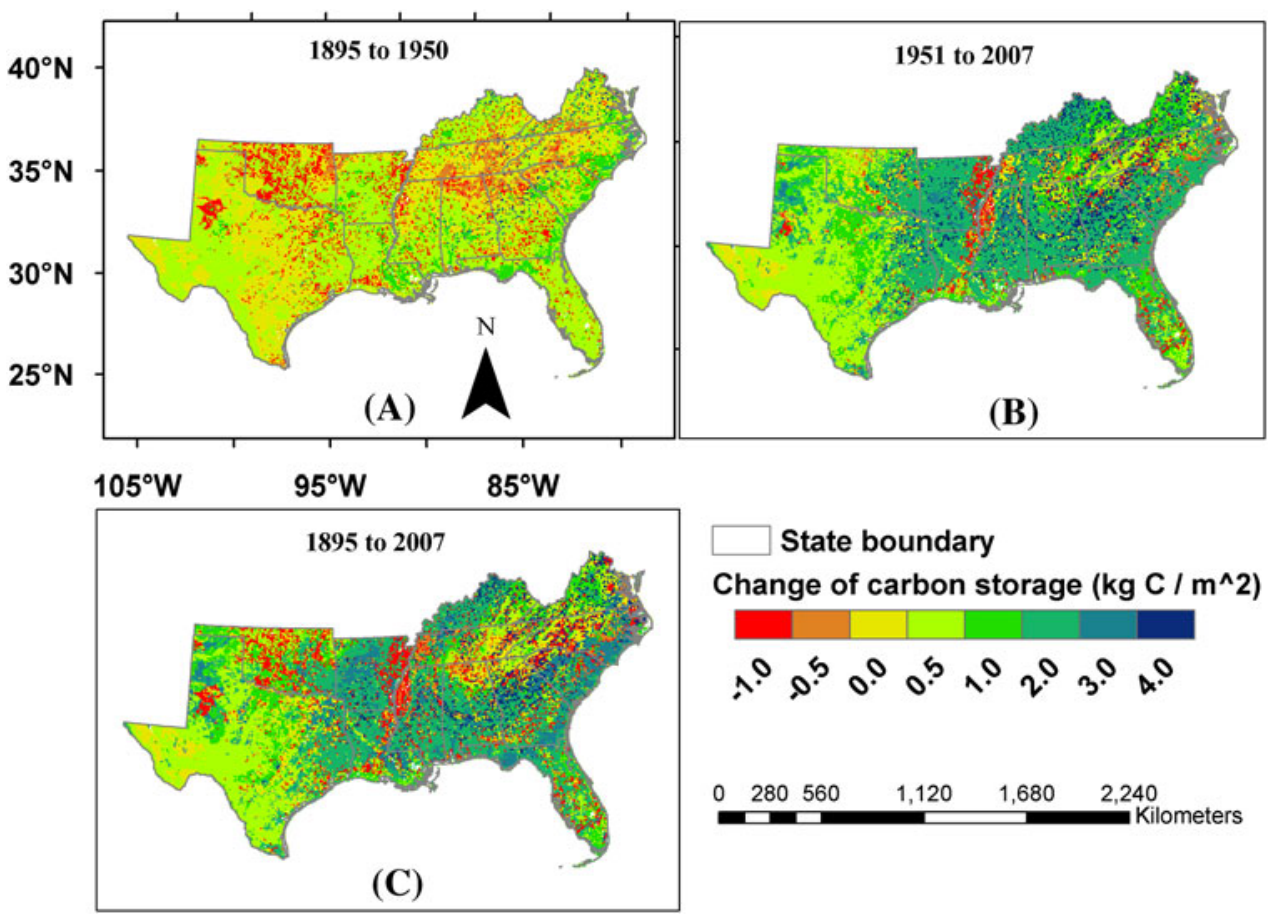

Figure 9. Cumulative NCE from A 1895 to 1950, B 1951 to 2007, and C 1895 to 2007. Negative value means $C$ source, whereas positive value means $\mathrm{C}$ sink.

wetland areas. Total C storage was also determined for each state (Figure 7C). During the 2007 regional drought, Texas had the highest terrestrial ecosystem C storage of any state $(4.17 \pm 0.39 \mathrm{Pg})$ due to its large land area. This was followed by Florida $(3.81 \pm 0.36 \mathrm{Pg})$, which has a large wetland area (about 18\% of the total land area) (Figure 1). Kentucky had the lowest $\mathrm{C}$ storage $(1.46 \pm 0.14 \mathrm{Pg})$.

Both the magnitude and distribution of $\mathrm{C}$ sinks and sources varied through time (Figure 9). From 1895 to 1951, the majority of the SUS was either a C source or a weak C sink (Figure 9A). During this period, LULCC was primarily due to conversion from natural vegetation to cropland (Figure 5G), which decreased $\mathrm{C}$ storage in most areas including Texas, Oklahoma, Arkansas Alabama and Georgia, and Tennessee (Figure 7C). By contrast, most regions and particularly the southeast area of the SUS region were dominated by strong $\mathrm{C}$ sinks between 1951 and 2007 (Figure 9B). For the entire period (that is, 1895 to 2007), C storage increased in most areas of the SUS, with the greatest increases in Kentucky and Virginia (about 10\%) and the greatest decrease $(6 \%)$ in Oklahoma (Figures 7C, 9C). C storage in Tennessee and Florida changed less than $1 \%$ during the entire study period (Figure 7C).

\section{Relative Contributions of Environmental Factors to C Storage Changes}

The simulation results indicate that changes in the five environmental factors (that is, climate, atmo- spheric $\mathrm{CO}_{2}$, tropospheric $\mathrm{O}_{3}$ concentrations, N deposition, and LULCC) resulted in a net land $\mathrm{C}$ sink in the SUS, with substantial interannual variability and spatial variations (Figure 6A). However, it is still unknown how much each factor contributed to this change. Therefore, factorial simulation experiments were used to identify the relative contribution of each factor and their interactions. Among the five environmental factors, LULCC (including $\mathrm{N}$ fertilizer application and irrigation in cropland) led to a net $\mathrm{C}$ source of $1.26 \mathrm{Pg}$ (Figure $10 \mathrm{~B}, \mathrm{C})$, accounting for $213 \%$ of the net $\mathrm{C}$ storage change from 1895 to 2007 (Table 3). Although cropland fertilizer use (Figure 4D) greatly increased C storage $(0.45 \mathrm{Pg} \mathrm{C})$, the long-term LULCC legacy effects appear to have largely offset this C sink.

The $30 \%$ increase in atmospheric $\mathrm{CO}_{2}$ concentrations from 1895 to 2007 contributed $1.94 \mathrm{Pg}$ to the SUS $\mathrm{C}$ sink. The increases in the atmospheric $\mathrm{CO}_{2}$ concentrations and $\mathrm{N}$ deposition caused the largest contribution of the five factors and consistently increased during the study period (Figure 4C). Nitrogen deposition resulted in a net $C$ sink of $0.48 \mathrm{Pg}$, contributing about $82 \%$ of the net change in $\mathrm{C}$ storage (Figure 10B, C; Table 3). Elevated $\mathrm{O}_{3}$ and climate change were less influential, reducing $\mathrm{C}$ storage by 0.58 and $0.40 \mathrm{Pg}$ during the study period. Increased $\mathrm{O}_{3}$ concentrations primarily influence $\mathrm{C}$ fluxes by reducing photosynthetic rates. Under the OZONE experiment, NPP for all the vegetation types was re- 

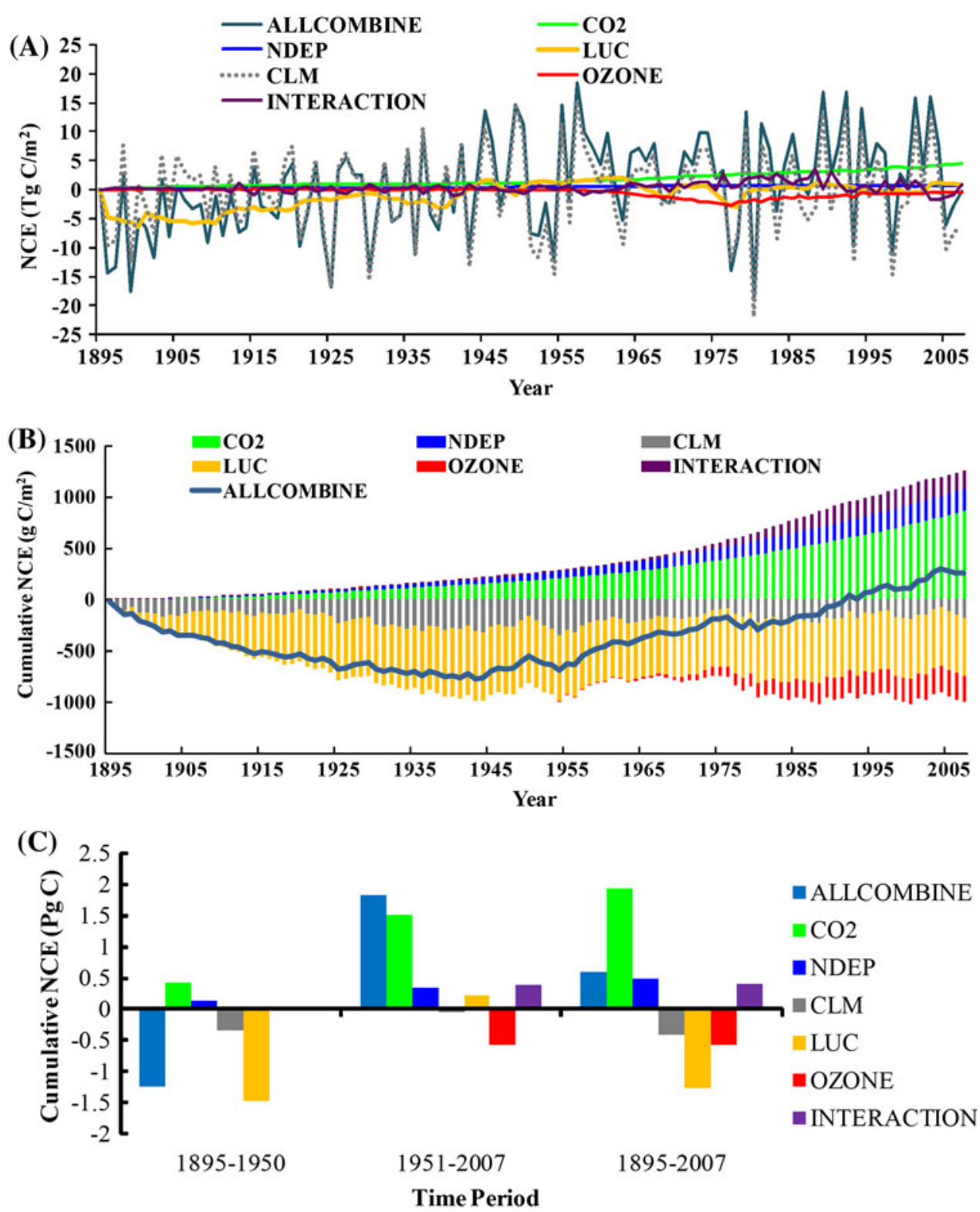

Figure 10. Impacts of environmental factors on annual and cumulative NCE in the SUS from 1895 to 2007 as simulated by the DLEM under different scenarios. A The temporal pattern of annual NCE; B The cumulative NCE under impacts of different environmental factors and their interactive effect; $\mathbf{C}$ The relative contribution of multiple environmental factors to NCE during three time periods ( 1895 to 1950,1951 to 2007 , and 1895 to 2007). INTERACTION means the interactive effect of multiple factors, INTERACTION $=$ ALCOMBINE - OZONE - LUC - CLM $-\mathrm{NDEP}-\mathrm{CO}_{2}$.

duced by $2.5 \%$ during the study period. Although the total contribution of long-term climate change to $\mathrm{C}$ losses was relatively small, the interannual variation of $\mathrm{C}$ fluxes under the combined experiment (ALLCOMBINE) was primarily controlled by climate change (CLM). Correlation analysis indicated that $85 \%\left(R^{2}=0.85 ; P<0.001\right)$ of $C$ flux variation was explained by climate variability.

\section{Interactive Effects among Multiple Environmental Factors}

The interactive effect of all environmental factors resulted in a $\mathrm{C}$ sink of $0.40 \mathrm{Pg} \mathrm{C}$ over the entire study period (Table 3). Some factors canceled each other out with regard to $\mathrm{C}$ sequestration such as the $\mathrm{N}$ deposition effect (0.48 Pg C) and climate change effect $(-0.40 \mathrm{Pg} \mathrm{C})$. This implied that complex 
Table 3. NCE and the Contribution of Different Factors in the SUS from 1895 to 2007

\begin{tabular}{|c|c|c|c|c|c|c|c|}
\hline \multirow[t]{2}{*}{ Periods } & \multirow[t]{2}{*}{ Storage change $(\mathrm{Pg} \mathrm{C})$} & \multicolumn{6}{|c|}{ Relative contribution $(\%)^{1}$} \\
\hline & & $\mathrm{CO}_{2}^{3}$ & NDEP & CLM & LUC & OZONE & INTERACTION \\
\hline $1895-1950$ & -1.24 & -33.95 & -10.62 & 27.76 & 119.18 & 0.00 & -2.29 \\
\hline $1951-2007$ & 1.83 & 82.78 & 19.22 & -2.94 & 12.04 & -31.71 & 20.58 \\
\hline $1895-2007$ & $0.59^{2}$ & 328.12 & 81.93 & -67.47 & -213.13 & -98.35 & 68.63 \\
\hline
\end{tabular}

interactions existed between these factors. The largest positive interactive effect was found between $\mathrm{CO}_{2}$ and $\mathrm{N}$ deposition (0.35 Pg C, Table 4), indicating increasing $\mathrm{N}$ deposition could enhance the $\mathrm{CO}_{2}$ fertilization effect. The largest negative interactive effect was found between climate warming and elevated atmospheric $\mathrm{CO}_{2}(-0.24 \mathrm{Pg}$ C), indicating that warming might weaken the $\mathrm{CO}_{2}$ fertilization effect on $\mathrm{C}$ sequestration. The slight increasing trend in precipitation (Figure 4A) resulted in a relatively large positive interaction (0.20 Pg C) between climate change and $\mathrm{N}$ deposition because $\mathrm{N}$ deposition rates were related to precipitation. Ozone-climate and $\mathrm{O}_{3}-\mathrm{CO}_{2}$ interactive effects contributed to $\mathrm{C}$ gains in the study region even though their interactions reduced NPP. One cause for the $\mathrm{C}$ gains resulting from the $\mathrm{CO}_{2}-$ $\mathrm{O}_{3}$ interaction was its positive effect on litter quantity, which likely led to increases in soil C storage. No significant interactive effects between other factors were found.

To further elucidate the mechanisms of the interaction between $\mathrm{N}$ deposition ( $\mathrm{N}$ availability) and atmospheric $\mathrm{CO}_{2}$, we analyzed their effects on natural vegetation types at the biome level, including evergreen needleleaf forest, deciduous broadleaf forest, arid shrubland, and grassland (Figure 11). The results indicate that the $\mathrm{CO}_{2}$

Table 4. Interactive Effects of Multiple Factors on NCE (Pg C)

\begin{tabular}{llllll}
\hline Factors & $\mathrm{CO}_{2}$ & NDEP & LUC & CLM & OZONE \\
\hline $\mathrm{CO}_{2}$ & 1.94 & & & & \\
$\mathrm{NDEP}$ & 0.35 & 0.48 & & & \\
$\mathrm{LUC}$ & -0.05 & 0.06 & -1.26 & & \\
$\mathrm{CLM}$ & -0.24 & 0.20 & 0.05 & -0.40 & \\
OZONE & 0.26 & -0.07 & 0.03 & 0.21 & -0.58 \\
\hline
\end{tabular}

Note: The numbers on the diagonal line are the effect of individual factors on NCE during 1895-2007, whereas other numbers are the interactive effect between two individual factors. fertilization effect on C storage was obviously enhanced by $\mathrm{N}$ deposition for all natural vegetation types except grassland (Figure 11E), where $\mathrm{N}$ deposition only slightly enhanced the $\mathrm{CO}_{2}$ fertilization effect. This interactive effect was less responsive at lower $\mathrm{N}$ deposition and atmospheric $\mathrm{CO}_{2}$ levels and increased at higher levels for all biome types except grassland.

\section{Spatial Variations in C Flux Caused by Changes in Individual Environmental Factors}

Although the interannual patterns were relatively simple for NCE as influenced by multiple environmental factors, the spatial patterns were more complex. Atmospheric $\mathrm{CO}_{2}$ concentration did not vary greatly over space. However, the impacts of elevated $\mathrm{CO}_{2}$ concentration could result in a $\mathrm{C}$ sink ranging from less than $150 \mathrm{~g} \mathrm{C} / \mathrm{m}^{2}$ in the west to over $2,500 \mathrm{~g} \mathrm{C} / \mathrm{m}^{2}$ in the east during the 1895 to 2007 period (Figure 12A). In general, elevated $\mathrm{CO}_{2}$ concentrations stimulated more $\mathrm{C}$ uptake in forests than other land-cover types. The $\mathrm{N}$ deposition rate in the SUS (Figure 5C, D) was generally lower than those in the northeastern US, where $\mathrm{N}$ saturation effects induced by excess $\mathrm{N}$ deposition have been reported (Pardo and others 2006). N deposition could result in a $\mathrm{C}$ sink ranging from 50 to $1,200 \mathrm{~g} \mathrm{C} / \mathrm{m}^{2}$ in the SUS (Figure $12 \mathrm{~B}$ ). Cropland was less responsive to increasing $\mathrm{N}$ deposition due to the large amount of $\mathrm{N}$ fertilizer applied to cropland. Although cropland area in the SUS did not change much from 1895 to 2007, the spatial distribution of cropland changed significantly, with decreased area in the northeast area of the SUS region and increased area in the northwest (Figure $5 \mathrm{G}$ ). In addition, urban areas increased rapidly since the 1970s. These general LULCC patterns resulted in $\mathrm{C}$ sinks in the northeast whereas the northwest was largely a C source (Figure 12C). However, $\mathrm{C}$ storage patterns were modified by 

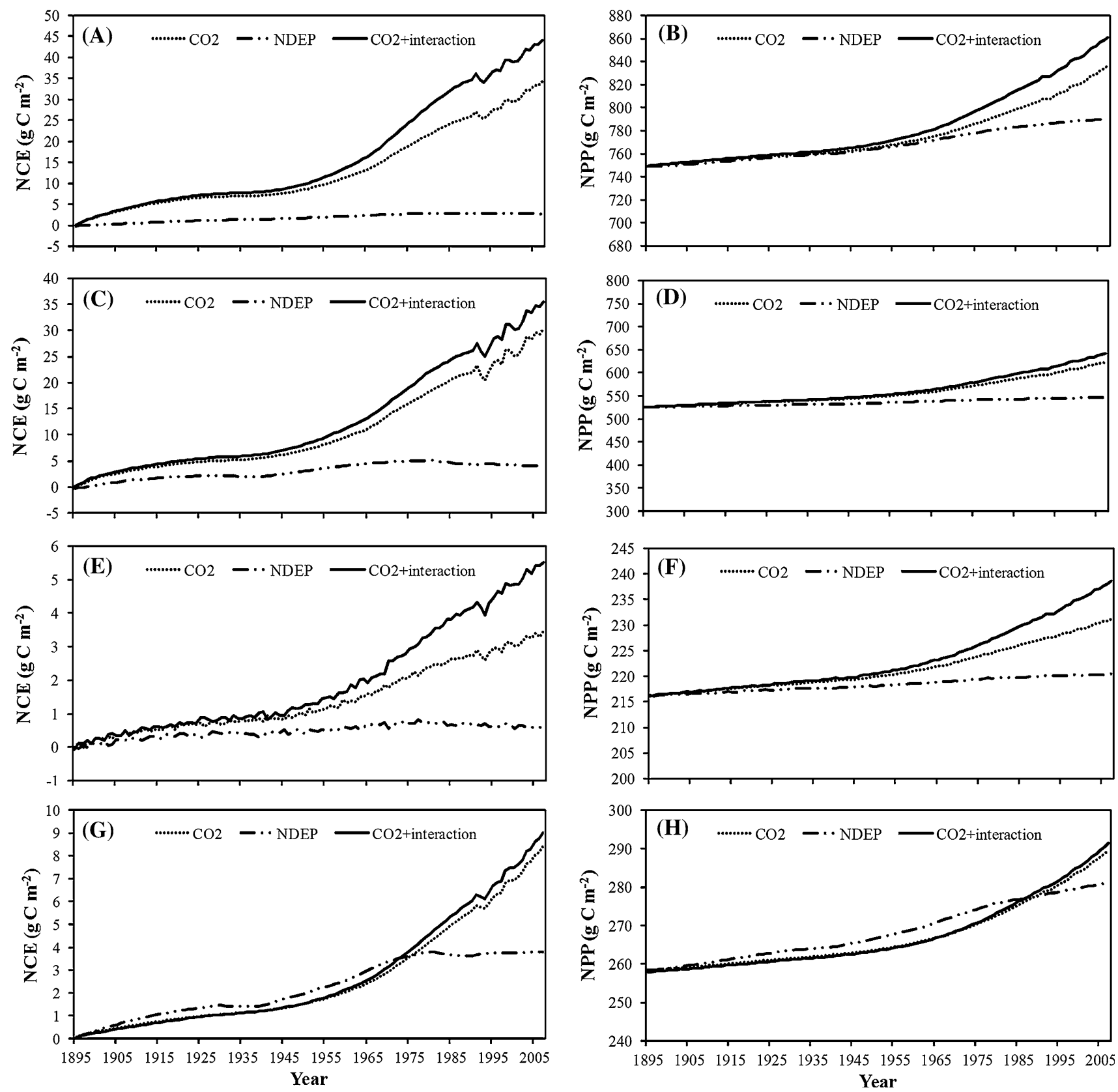

Figure 11. Interactive effects between $\mathrm{N}$ deposition and atmospheric $\mathrm{CO}_{2}$ on NCE $\left(\mathrm{g} \mathrm{C} / \mathrm{m}^{2}\right)$ and NPP $\left(\mathrm{g} \mathrm{C} / \mathrm{m}^{2}\right)$ for different biomes in the SUS. A, B deciduous broadleaf forest; C, D evergreen needleleaf forest; $\mathbf{E}, \mathbf{F}$ shrubland; $\mathbf{G}, \mathbf{H}$ grassland. Note $\mathrm{CO}_{2}$ : $\mathrm{CO}_{2}$ only experiment; NDEP: $\mathrm{N}$ deposition only experiment; $\mathrm{CO}_{2}+$ interaction: $\mathrm{CO}_{2}$ only effects plus interactive effects between $\mathrm{CO}_{2}$ and $\mathrm{N}$ deposition.

cropland irrigation and $\mathrm{N}$ fertilizer use, resulting in $\mathrm{C}$ sinks in a few areas in the northwest. Climate change could result in both $\mathrm{C}$ sources and sinks in the SUS (Figure 12D). Large C sources found in the northeast area of the SUS region and Florida were primarily due to drought impacts whereas a strong C sink occurred in the west area of the SUS region due to increased precipitation. Increased tropospheric $\mathrm{O}_{3}$ induced large $\mathrm{C}$ sources in the northeast area of the SUS region (Figure 12E). The influences of tropospheric $\mathrm{O}_{3}$ concentrations on the photosynthesis of broadleaf forest and cropland increased $\mathrm{C}$ emissions in these areas. Interactive effects among multiple environmental factors caused large $\mathrm{C}$ sinks in the northeast area of the SUS region (Figure 12F) but resulted in C sources in areas dominated with cropland and wetlands. 

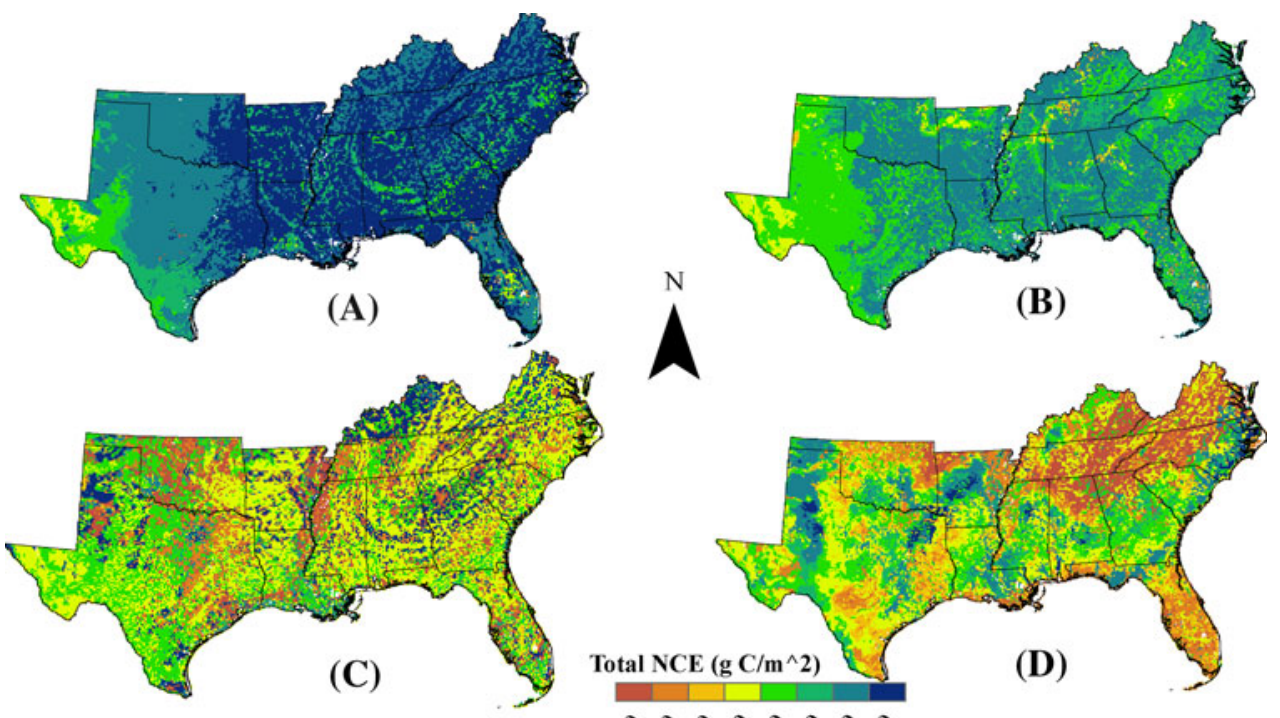

Figure 12. Effects of multiple environmental changes on cumulative NCE (Pg C) in the SUS from 1895 to 2007. A $\mathrm{CO}_{2}$ experiment; B NDEP; C LUC; D CLM; E OZONE; F Interactive effects among multiple factors.

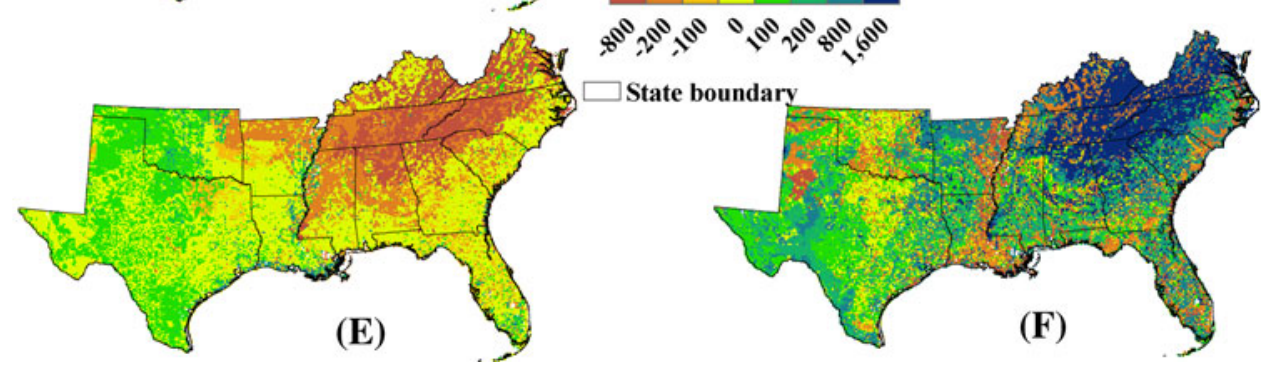

\section{Discussion}

\section{Ecosystem C Storage and Flux in the SUS}

Han and others (2007) estimated that total C storage was $21 \mathrm{Pg}$ in 11 states of the SUS (Oklahoma and Kentucky were excluded), which is $25 \%$ lower than our estimation of $26 \mathrm{Pg} \mathrm{C}$. Despite this difference, both studies reported that Texas has the largest $\mathrm{C}$ storage, followed by Florida. The lower value estimated by Han and others (2007) may be partly due to the exclusion of $\mathrm{C}$ storage in litter, coarse wood debris, wood products, grassland biomass, and harvested crop products. All these pools have large spatial and interannual variations, and thus could not be simply represented by a regional mean value. Unlike the empirical approach used by Han and others (2007), our study not only directly addressed the spatial and temporal heterogeneity of SUS ecosystems but also the daily variations of $\mathrm{C}$ pools in response to environmental changes.

Our simulated NCE for different time periods between 1895 and 2007 was comparable to the reported mean annual NCE from several other studies on national or continental scales (Table 5). We found that the SUS experienced a transition from $C$ source to $C$ sink during the 1950s. In this study, we considered the effects of climate change, atmospheric chemical composition, and LULCC. Most previous work only included a subset of these factors. The study by Schimel and others (2000), for example, did not consider the effect of LULCC, one of the most important factors controlling ecosystem $\mathrm{C}$ balance in the SUS since the seventeenth century (Delcourt and Harris 1980). Houghton and others (1999) only focused on the effects of LULCC and ignored the impacts of other environmental factors. Furthermore, our study quantified $\mathrm{C}$ fluxes at a higher frequency (daily) and at a higher spatial resolution $(8 \mathrm{~km} \times 8 \mathrm{~km})$ compared to the inverse model (for example, Peters and others 2007) or empirical approaches (for example, Pacala and others 2007) used by previous investigators. This approach enabled us to show that the recovery of the soil $\mathrm{C}$ pool lagged behind the regrowth of vegetation biomass. For example, the soil in this region has a greater potential to accumulate $\mathrm{C}$ than did vegetation. Although total ecosystem $\mathrm{C}$ storage has increased by $0.80 \mathrm{Pg} \mathrm{C}$, about 0.20 Pg C has been lost from the soil in the SUS from 1895 to 2007 (Table 3), mainly due to the LULCC legacy effect. This analysis revealed a relatively complex pattern in the dynamics of soil $\mathrm{C}$ pools (Table 3 ). 
Table 5. Comparison of Simulated NCE Against the Estimates from Other Previous Studies

\begin{tabular}{|c|c|c|c|c|c|}
\hline \multirow[t]{2}{*}{ Source } & \multirow[t]{2}{*}{ Method } & \multirow[t]{2}{*}{ Study region } & \multirow[t]{2}{*}{ Time period } & \multicolumn{2}{|c|}{$\begin{array}{l}\text { Mean annual C sink } \\
\left(\mathrm{g} \mathrm{C} / \mathrm{m}^{2} / \mathrm{y}\right)\end{array}$} \\
\hline & & & & Other study & This study \\
\hline Ciais and others (1995) & $\delta^{13} \mathrm{C}$ measurements & $\begin{array}{l}\text { Northern } \\
\text { mid-latitudes }\end{array}$ & 1992 & $33-55$ & 50 \\
\hline Houghton and others (1999) & Book Keeping Model & $\mathrm{US}^{1}$ & $1980 \mathrm{~s}$ & $16-38$ & 14 \\
\hline Pacala and others (2007) & $\begin{array}{l}\text { Literature review and } \\
\text { synthesis }\end{array}$ & US & Current & 53 & $27^{2}$ \\
\hline Schimel and others $(2000)^{3}$ & Biogeochemical models & Southeast US & 1980-1993 & 15 & 20 \\
\hline Schimel and others (2001) & Inverse model & North America & 1990-1994 & 32 & 30 \\
\hline Peters and others (2007) & $\begin{array}{l}\text { Inverse model: } \\
\text { CarbonTracker }\end{array}$ & SUS & 2000-2007 & 29.1 & 23.7 \\
\hline
\end{tabular}

\section{Relative Contributions of Individual Environmental Change Factors}

Some previous studies have suggested that the SUS was a net $\mathrm{C}$ sink during the past century. However, most of these studies only included a single or a few factors and could not clearly explain the causes of this $C$ sink. In this study, we included multiple environmental factors to more accurately estimate the spatial and temporal changes in C storage and their causes. Single factor experiments have suggested that fertilization effects from elevated $\mathrm{CO}_{2}$, $\mathrm{N}$ deposition, and $\mathrm{N}$ fertilizer consistently stimulated $\mathrm{C}$ sequestration, whereas increases in $\mathrm{O}_{3}$ concentrations led to a consistent $\mathrm{C}$ loss since the 1950s. However, the impacts of climate and LULCC could vary through time.

The SUS has experienced three distinct periods in LULCC since the 1700s (Wear 2002; Chen and others 2006; Hansen and others 2010). From 1895 to 1950, the SUS experienced a period of cropland expansion, resulting in a large $\mathrm{C}$ emission. We found the LULCC shifted from a $C$ source to a $C$ sink in the early 1950s. This pattern has also been reported by Chen and others (2006) and Houghton and others $(1999,2003)$. LULCC was a net C sink of $0.23 \mathrm{Pg}$ after 1945 , which is about $10 \%$ of the reported C sink resulting from LULCC for the continental US (about 2.4 Pg C as estimated by Houghton 2003). From 1895 to 2007, LULCC resulted in a C source of $1.26 \mathrm{Pg}$, contributing approximately $30 \%$ of the C source induced by LULCC for the continental US during approximately the same period (4.1 Pg C as estimated by Houghton 2003). Although cropland area in 1895 was similar to that in 2007 and cropland area abandoned for forests and $\mathrm{N}$ fertilizer applications has greatly increased since the 1950s. LULCC still resulted in the largest $C$ source in the SUS from 1895 to 2007. This implied that C storage did not fully recover to the 1895 level from the 1950s to the 2000s. LULCC legacy effects on C sources may be long lasting (for example, 100 years) and therefore short-term studies (for example, Han and others 2008) or static extrapolations (for example, Houghton and others 1999, 2003) could underestimate LULCC impacts.

Our study suggests that elevated $\mathrm{CO}_{2}$ was the largest contributor to $\mathrm{C}$ sequestration in the SUS. However, the impacts of elevated $\mathrm{CO}_{2}$ may be constrained by other factors such as climate, landuse history, and $\mathrm{N}$ availability (Norby and others 2005; Johnson 2006; Luo and others 2004, 2008). Meta-data analysis indicated that a doubling of the $\mathrm{CO}_{2}$ concentration could stimulate NPP by a median value of $23 \%$ for forest (Norby and others 2005) and stimulate $\mathrm{C}$ storage within a wide range of environmental conditions. We found that across all vegetation types, a $30 \%$ increase in the $\mathrm{CO}_{2}$ concentration from 1895 to 2007 stimulated NPP by $12 \%$ and $\mathrm{C}$ storage by $6 \%$, and stimulated forest NPP by $12 \%$ and C storage by 12 and $6 \%$ in the SUS.

Increased $\mathrm{O}_{3}$ concentrations decreased NPP by $3 \%$ and $\mathrm{C}$ storage $2 \%(0.58 \mathrm{Pg} \mathrm{C})$, for all vegetation types, 3 and $5 \%$ for deciduous broadleaf forest, 0.5 and $0.3 \%$ for evergreen needleleaf forest, and 7 and $5 \%$ for cropland. Our simulated $\mathrm{O}_{3}$ impacts on NPP and C storage were within the range of field observational data and other model simulations in 
the continental US (Heck and others 1984; Pye 1988; Ollinger and others 2002; Felzer and others 2004). In addition, we found that $\mathrm{O}_{3}$ had the largest impacts on NPP and C storage of deciduous broadleaf forest and cropland, which was also consistent with previous studies (Chameides and others 1994; Chapelka and Samulson 1998; Ollinger and others 2002; Felzer and others 2004; Ren and others 2007b; Zhang and others 2007).

Elevated $\mathrm{N}$ deposition resulted in $\mathrm{C}$ sinks ranging from 0.44 to $2.0 \mathrm{Pg} \mathrm{C} / \mathrm{y}$ in global terrestrial ecosystems (Nadelhoffer and others 1999; Churkina and others 2007; Jain and others 2009). Reay and others (2008) also reported that elevated N deposition could sequester $1-2 \%$ of the global anthropogenic C emissions (about 8.5 Pg C in 2007, Boden 2009). We found elevated $\mathrm{N}$ deposition induced a C sink of 0.48 Pg and increased NPP by $5 \%$ for all vegetation types from 1895 to 2007 . N deposition contributed $9.6 \%$ to the net $\mathrm{C}$ change in the SUS, which is within the lower end of the reported range for global terrestrial ecosystems (that is, Nadelhoffer and others 1999), presumably due to a lower $\mathrm{N}$ deposition rate in the SUS compared with other regions of the US, and because there were no interacting effects with $\mathrm{N}$ deposition in our study. If interacting effects such as elevated $\mathrm{CO}_{2}$ are included, the total effect would be closer to $0.40 \mathrm{Pg}$ $\mathrm{C}$ or about $18 \%$ of the net $\mathrm{C}$ changes in the SUS in our study. Although $\mathrm{N}$ saturation effects (for example, NPP reduction, increased $\mathrm{C}$ and $\mathrm{N}$ leaching) have been reported in the northeastern US, we did not find this phenomenon in the SUS (Boggs and others 2005), presumably due to the lower $\mathrm{N}$ deposition rate and higher rates of $\mathrm{N}$ uptake from younger forests in the SUS (Pan and others 2011; Smith and others 2009; Lu and others 2012).

Climate change has been reported to either increase or decrease C storage, depending on approaches used and studied regions (for example, Schimel and others 2000; McGuire and others 2001; Luo and others 2008). In our study, the longterm effect of climate change on $\mathrm{C}$ storage was small $(-0.40 \mathrm{Pg})$ compared to the effects of other factors (Table 4; Figure 10B, C). However, we found that interannual climate patterns had an important influence over interannual variations in $\mathrm{C}$ fluxes. In addition, climatic patterns varied across the region. Although a general increase in drought intensity and frequency in the SUS has not been reported (Chen and others 2012), drought events still resulted in a C source of 0.16 Pg from 1895 to 2007 and most areas in the northeastern part of the SUS region were $\mathrm{C}$ sources in our analysis (Figure 13A). The long-term effect of drought on C

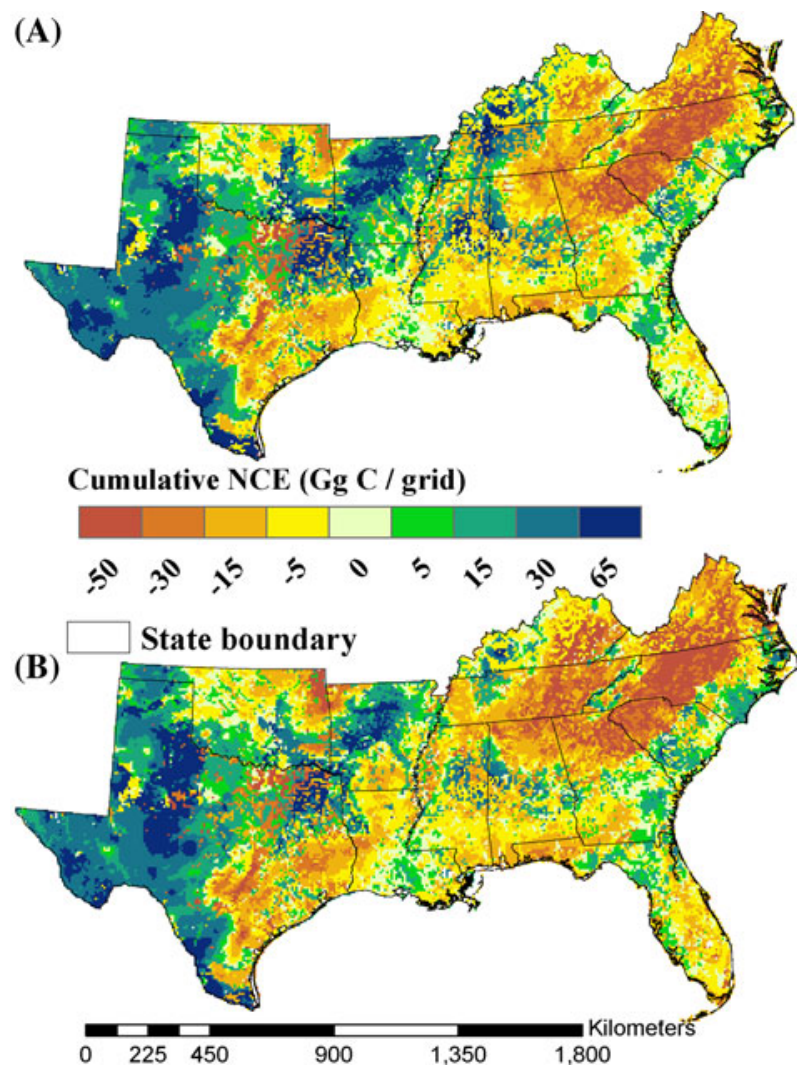

Figure 13. Spatial distribution of accumulated NCE (Gg $\mathrm{C} /$ grid; $1 \mathrm{Gg}=10^{9} \mathrm{~g}$ ) as influenced by precipitation only (A) and climate change (B) from 1895 to 2007.

sources was also enhanced by changes in other climate factors (for example, air temperature and radiation). Climatic extremes, including hot and dry events, could significantly modify the spatial distribution of $\mathrm{C}$ sinks and sources in the SUS. For example, our simulation showed that large amounts of $\mathrm{C}$ were released during the 1988 to 1989 drought when the SUS experienced a strong La Niňa with a dry winter, whereas an El Niňo in 1991 to 1992 was accompanied by a significant C sink due to the higher precipitation

\section{Interactive Effects among Multiple Environmental Factors}

The combined impacts of multiple environmental factors on $\mathrm{C}$ dynamics are not simply the additive effects of all the individual factors. Interactive effects have been previously reported (for example, Rastetter and others 1997; Ollinger and others 2002; Shaw and others 2002; McLaughlin and others 2007; Luo and others 2008; Tian and others 2010a, Tian and others 2010b). In our study, the interactions among multiple factors induced a large C sink from 1895 to 2007, which offset C emissions 
induced by climate change alone. However, the importance of the interactive effects changed over time. Prior to 1950, the interactive effects were negligible but after 1950 they resulted in a large C sink. Interactions among multiple factors are complex, and more experimental and observational data will be needed to understand them.

The most significant interactive effect occurred between elevated $\mathrm{N}$ deposition and atmospheric $\mathrm{CO}_{2}$, which was also observed by Tian and others (2010b). Our study also found that the interactive effect between $\mathrm{N}$ deposition and atmospheric $\mathrm{CO}_{2}$ increased with elevated $\mathrm{N}$ input, implying a stronger $\mathrm{N}$ limitation with increasing atmospheric $\mathrm{CO}_{2}$. This is consistent with the progressive $\mathrm{N}$ limitation hypothesis that $\mathrm{CO}_{2}$ fertilization effects will not be sustained in the long term without external $\mathrm{N}$ input (Luo and others 2004; Finzi and others 2006; Johnson 2006).

\section{Uncertainties and Future Research}

Although this analysis was intended to simulate the contributions of individual factors and their combined effects, it is also important to recognize the inherent uncertainties in such a regional-scale study. The influences of changes in individual factors on $\mathrm{C}$ storage estimates could not be fully corroborated due to lack of adequate long-term observational or experimental data in the study region (Popper 1968; Oreskes and others 1994; Rastetter 1996). The DLEM attempts to include the most important processes controlling regional $\mathrm{C}$ dynamics. However, other processes beyond the scope of this model or for which data are lacking may prove to be equally important. For example, forest management (for example, harvest, thinning, and $\mathrm{N}$ fertilizer use) and land disturbance (for example, hurricane, fire, and insects) were not considered in this study. These factors alter ecosystem structure and function and influence $\mathrm{C}$ fluxes, especially during recent decades. Another uncertainty is the legacy effect of historical disturbances in the study region (Chen and others 2006). In our study, we developed the simulation baseline for all the major $\mathrm{C}, \mathrm{N}$, and water pools (for example, vegetation, soil, and litter $\mathrm{C}$ and $\mathrm{N}$, soil water content) for 1895 by running the model to equilibrium status, which assumes that the effects of disturbance on vegetation were not significant at that time. This assumption is currently used by many other process-based models (Huntzinger and others 2012) and may lead to overestimation of the baseline $\mathrm{C}$ pool size, and therefore the estimated $\mathrm{C}$ loss rate due to LULCC in the early twentieth century.

\section{Conclusions}

We explored century-scale regional $\mathrm{C}$ dynamics in response to changes in climate, atmospheric $\mathrm{CO}_{2}$ concentration, tropospheric $\mathrm{O}_{3}, \mathrm{~N}$ deposition, and LULCC in the SUS from 1895 to 2007 using the DLEM and long-term historical environmental data. Our results suggest that SUS terrestrial ecosystems were a $\mathrm{C}$ sink of $0.80 \pm 0.38 \mathrm{Pg}$ during this period. An important finding of our study was that SUS ecosystems shifted from a C source between 1895 and 1950 to a C sink from 1951 to 2007. The C sink was primarily due to increased $\mathrm{C}$ accumulation in vegetation while the soil $\mathrm{C}$ pool declined during the study period. Large spatial variations in the impacts of multiple factors on $\mathrm{C}$ dynamics were primarily related to LULCC and precipitation patterns. Elevated atmospheric $\mathrm{CO}_{2}$ concentration, $\mathrm{N}$ deposition, and their interactions were the primary causes of $\mathrm{C}$ sinks in our study, whereas changes in tropospheric $\mathrm{O}_{3}$, LULCC, and climate were the primary causes of $\mathrm{C}$ losses. Elevated $\mathrm{CO}_{2}$ concentration was the largest contributor to $C$ sequestration, whereas LULCC was the largest contributor to $\mathrm{C}$ losses. Interactions among multiple factors were complex, but resulted in a large $\mathrm{C}$ sink. The interactive effect between $\mathrm{N}$ deposition and atmospheric $\mathrm{CO}_{2}$ continuously increased with elevated $\mathrm{N}$ input, implying stronger $\mathrm{N}$ limitation with increasing atmospheric $\mathrm{CO}_{2}$. Additional field experiments and observations are needed to identify the contributions of individual factors and their interactions to $\mathrm{C}$ dynamics.

\section{ACKNOWLEDGMENTS}

This study has been supported by the US Department of Energy National Institute for Climate Change Research (NICCR) Program (DUKE-UN07-SC-NICCR-1014), NASA Interdisciplinary Science Program (NNX10AU06G), NASA Terrestrial Ecology Program, Alabama Agricultural Experiment Station Research Program (AAES), and the Southern Forest Research Partnership. We would also thank Dr. Edward Rastetter and two anonymous reviewers who have provided thoughtful comments and suggestions, which led to a major improvement in the manuscript.

\section{REFERENCES}

Alexander RB, Smith RA. 1990. County-level estimates of nitrogen and phosphorus fertilizer use in the United States, 1945 to 1985. U.S. Geological Survey Open-File Report 90130.

Birdsey RA, Lewis BM. 2003. Carbon in U.S. forests and wood products, 1987-1997: state-by-state estimates. Gen. Tech. 
Rep. NE-310, Washington, DC: U.S. Department of Agriculture, Forest Service.

Birdsey RA, Pregitzer K, Lucier A. 2006. Forest carbon management in the United States: 1600-2100. J Environ Qual 35:1461-9.

Boden TA, Marland G, Andres RJ. 2009. Global, regional, and National fossil-fuel $\mathrm{CO}_{2}$ emissions. Carbon Dioxide Information Analysis Center, Oak Ridge National Laboratory, U.S. Department of Energy, Oak Ridge, Tenn., USA. doi:10.3334/ CDIAC/00001.

Boggs JL, McNulty SG, Gavazzi MJ, Moore JM. 2005. Tree growth, foliar chemistry, and nitrogen cycling across a nitrogen deposition gradient in southern Appalachian deciduous forests. Can J For Res 35:1901-13.

Chameides WL, Kasibhatla PS, Yienger J, Levy H. 1994. Growth of continental-scale metro-agro-plexes, regional ozone pollution, and world food production. Science 264:74-7.

Chapelka AH, Samulson LJ. 1998. Ambient ozone effects on forest trees of the eastern United States: a review. New Phytologist 139:91-108.

Chen H, Tian H. 2005. Does a general temperature-dependent $\mathrm{Q}_{10}$ model of soil respiration exist at biome and global scale? J Integr Plant Biol 47:1288-302. doi:10.1111/j.1744-7909. 2005.00211.x

Chen H, Tian H, Liu M, Melillo J, Pan S, Zhang C. 2006. Effect of land-cover change on terrestrial carbon dynamics in the Southern USA. J Environ Qual 35:1533-47.

Chen G, Tian H, Zhang C, Liu M, Ren W, Zhu W, Chappelka A, Prior SA, Lockaby GB. 2012. Drought in the Southern United States over the 20th century: variability and its impacts on terrestrial ecosystem productivity and carbon storage. Climatic Change. doi:10.1007/s10584-012-0410-z.

Churkina G, Trusilova K, Vetter M, Dentener F. 2007. Contribution of nitrogen deposition and forest regrowth to terrestrial carbon uptake. Carbon Balance Manag 2:5. doi:10.1186/ 1750-0680-2-5.

Curtis PS, Wang X. 1998. A meta-analysis of elevated $\mathrm{CO}_{2}$ effects on woody plant mass, form, and physiology. Oecologia 113 : 299-313.

Delcourt HR, Harris WF. 1980. Carbon budget of the southeastern United States: analysis of historic change in trend from source to sink. Science 210:321-3.

Dentener FJ. 2006. Global maps of atmospheric nitrogen deposition, 1860, 1993, and 2050. Available online http://daac.ornl.gov/ from Oak Ridge National Laboratory Distributed Active Archive Center, Oak Ridge, Tennessee, USA.

Enting IG, Wigley TML, Heimann M. 1994. Future emissions and concentrations of carbon dioxide: key ocean/atmosphere/ land analyses. CSIRO Division of Atmospheric Research Tech Paper No. 31, Melbourne.

Ellsworth DS. 1999. $\mathrm{CO}_{2}$ enrichment in a maturing pine forest: are $\mathrm{CO}_{2}$ exchange and water status in the canopy affected? Plant Cell Environ 22:461-72.

Felzer B, Kicklighter DW, Melillo JM, Wang C, Zhuang Q, Prinn R. 2004. Effects of ozone on net primary production and carbon sequestration in the Conterminous United States using a biogeochemistry model. Tellus 56B:230-48.

Finzi AC, Moore DJ, DeLucia EH, Kim HS, Jackson RB, Lichter J, McCarthy H, Oren R, Pippen JS, Schlesinger WH. 2006. Progressive nitrogen limitation of ecosystem processes under elevated $\mathrm{CO}_{2}$ in a warm-temperate forest. Ecology 87: $15-25$.
Han FX, Plodinec MJ, Su Y, Monts DL, Li Z. 2007. Terrestrial carbon pools in southeast and south-central United States. Climatic Change 84:191-202.

Hansen C, Yonavjak L, Clarke C, Minnemeyer S, Boisrobert L, Leach A, Schleeweis K. 2010. Southern forests for the future. World Resources Institute. http://www.wri.org/project/ southern-forests.

Heck WW, Cure WW, Rawlings JO, Zaragoza LJ, Heagle AS, Heggestad HE, Kohut RJ, Kress LW, Temple PJ. 1984. Assessing impacts of ozone on agricultural crops: II. Crop yield functions and alternative exposure statistics. J Air Pollut Control Assoc 34:810-17.

Homer C, Dewitz J, Fry J, Coan M, Hossain N, Larson C, Herold N, McKerrow A, VanDriel JN, Wickham J. 2007. Completion of the 2001 National Land Cover Database for the conterminous United States. Photogram Eng Remote Sens 73:337-41.

Houghton RA. 2003. Revised estimates of the annual net flux of carbon to the atmosphere from changes in land use and land management 1850-2000. Tellus 55B:378-90.

Houghton RA, Hackler JL, Lawrence KT. 1999. The U.S. carbon budget: contributions from land-use change. Science 285:574-8.

Huntzinger DN, Post WM, Wei Y, Michalak AM, West TO, Jacobson AR, Baker IT, Chen JM, Davis KJ, Hayes DJ, Hoffman FM, Jain AK, Liu S, McGuire AD, Neilson RP, Poulter B, Raczka BM, Tian HQ, Thornton P, Tomelleri E, Viovy N, Xiao J, Zeng N, Zhao M, Cook R. 2012. North American Carbon Project (NACP) regional interim synthesis: terrestrial biospheric model intercomparison. Ecol Model 232:144-57. doi:10.1016/j.ecolmodel.2012.02.004

Jain A, Yang X, Kheshgi H, McGuire AD, Post W, Kicklighter D. 2009. Nitrogen attenuation of terrestrial carbon cycle response to global environmental factors. Glob Biogeochem Cycles. doi:10.1029/2009GB003519.

Johnson DW. 2006. Progressive N limitation in forests: review and implications for long-term responses to elevated $\mathrm{CO}_{2}$ Ecology 87:64-75.

Karl TR, Melillo JM, Peterson TC. 2009. Global climate change impacts in the United States. Cambridge: Cambridge University Press.

Liu M, Tian H, Chen G, Ren W, Zhang C, Liu J. 2008. Effects of land use and land cover change on evapotranspiration and water yield in China during the 20th century. J Am Water Resour Assoc (JAWRA) 44:1193-207. doi:10.1111/j.17521688.2008.00243.

Liu M, Tian H, Lu C, Xu X, Chen G, Ren W. 2012. Effects of multiple environment stresses on evapotranspiration and runoff over eastern China. J Hydrol 426-427:39-54.

Lu C, Tian H, Liu M, Ren W, Xu X, Chen GS, Zhang C. 2012. Effect of nitrogen deposition on China's terrestrial carbon uptake in the context of multi-factor environmental changes. Ecol Appl 22:53-75.

Luo Y, Su B, Currie WS, Dukes JS, Finzi A, Hartwig U, Hungate B, McMurtrie RE, Oren R, Parton WJ, Pataki DE, Shaw MR, Zak DR, Field CB. 2004. Progressive nitrogen limitation of ecosystem responses to rising atmospheric $\mathrm{CO}_{2}$. Bioscience 54:731-9.

Luo Y, Gerten D, le Maire G, Parton WJ, Weng ES, Zhou XH, Keough C, Beier C, Ciais P, Cramer W, Dukes JS, Emmett B, Hanson PJ, Knapp A, Linder S, Nepstad D, Rustad L. 2008. Modelled interactive effects of precipitation, temperature, and $\mathrm{CO}_{2}$ on ecosystem carbon and water dynamics in different climatic zones. Glob Change Biol 14:1986-99. 
Malmsheimer RW, Heffernan P, Brink S, Crandall D, Deneke F, Galik C, Gee E, Helms JA, McClure N, Mortimer M, Ruddell S, Smith M, Stewart J. 2008. Forest management solutions for mitigating climate change in the United States. J Forestry 106:115-73.

McGuire AD, Sitch S, Clein JS, Dargaville R, Esser G, Foley J, Heimann M, Joos F, Kaplan J, Kicklighter DW, Meier RA, Melillo JM, Moore IIIB, Prentice IC, Ramankutty N, Reichenau T, Schloss A, Tian H, Williams LJ, Wittenberg U. 2001. Carbon balance of the terrestrial biosphere in the twentieth century: analyses of $\mathrm{CO}_{2}$, climate and land-use effects with four process-based ecosystem models. Glob Biogeochem Cycles 15:183-206.

McLaughlin SB, Nosal M, Wullschleger SD, Sun G. 2007. Interactive effects of ozone and climate on tree growth and water use in a Southern Appalachian forest in the USA. New Phytologist 174:109-24.

McNulty SG, Boggs JL. 2010. A conceptual framework: redefining forest soil's critical acid loads under a changing climate. Environ Pollut 158:2053-8.

Melillo JM, Steudler PA, Aber JD, Newkirk K, Lux H, Bowles FP, Catricala C, Magill A, Ahrens T, Morrisseau S. 2002. Soil warming and carbon cycle feedbacks to the climate system. Science 298:2173-6.

Mesinger F, DiMego G, Kalnay E, Shafran P, Ebisuzaki W, Jovic D, Woollen J, Rogers E, Berbery EH, Ek M, Fan Y, Grumbine R, Higgins W, Li H, Lin Y, Manikin G, Parrish D, Shi W. 2006. North American regional reanalysis. Bull Am Meteorol Soc. doi:10.1175/BAMS-B7-3-343.

Miller DA, White RA. 1998. A conterminous United States multi-layer soil characteristics data set for regional climate and hydrology modeling. Earth Interact 2:1-26.

Myneni RB, Keeling CD, Tucker CJ, Asrar G, Nemani RR. 1997. Increased plant growth in the northern high latitudes from 1981 to 1991. Nature 386:698-702.

Norby RJ, DeLucia EH, Gielen B, Calfapietra C, Giardina CP, King JS, Ledford J, McCarthy HR, Moore DJP, Ceulemans R, De Angelis R, Finzi AC, Karnosky DF, Kubiske ME, Lukac M, Pregitzer KS, Scarascia-Mugnozza GE, Schlesinger WH, Oren R. 2005. Forest response to elevated $\mathrm{CO}_{2}$ is conserved across a broad range of productivity. Proc Natl Acad Sci 102: 18052-6.

Ollinger SV, Aber JD, Reich PB, Freuder RJ. 2002. Interactive effects of nitrogen deposition, tropospheric ozone, elevated $\mathrm{CO}_{2}$ and land use history on the carbon dynamics of northern hardwood forests. Glob Change Biol 8:545-62.

Oren R, Ellsworth DS, Johnsen KH, Phillips N, Ewers BE, Maier C, Schafer KVR, McCarthy H, Hendrey G, McNulty SG, Katul GG. 2001. Soil fertility limits carbon sequestration by forest ecosystems in a $\mathrm{CO}_{2}$ - enriched atmosphere. Nature 411:46972.

Oreskes N, Shrader-Frechette K, Belitz K. 1994. Verification, validation, and confirmation of numerical models in earth sciences. Science 263:641-6.

Pacala S, Birdsey R, Bridgham S, Conant RT, Davis K, Hales B, Houghton RA, Jenkins JC, Johnston M, Marland G, Paustian K. 2007. The North American carbon budget past and present. In: King AW, Dilling L, Zimmerman GP, Fairman DM, Houghton RA, Marland G, Rose AZ, Wilbanks TJ, Eds. The first state of the carbon cycle report (SOCCR): the North American carbon budget and implications for the global carbon cycle. Asheville: National Oceanic and Atmospheric Administration, National Climatic Data Center. p 29-36.
Pan Y, Chen JM, Birdsey R, McCullough K, He L, Deng F. 2011. Age structure and disturbance legacy of North American forests. Biogeosciences 8:715-32.

Pardo LH, Templer PH, Goodale C, Duke S, Groffman P, Adams MB, Boeckx P, Boogs J, Campbell J, Colman B, Compton J, Emmett B, Gundersen P, Kjonaas J, Lovett G, Mack M, Magill A, Mbila M, Mitchell M, McGee G, McNulty S, Nadelhoffer K, Ollinger S, Ros D, Rueth H, Rustad L, Shaberg P, Schiff S, Schleppi P, Spoelstra J, Wessel W. 2006. Regional assessment of $\mathrm{N}$ saturation using foliar ${ }^{15} \mathrm{~N}$. Biogeochemistry 80:143-71.

Peters W, Jacobson AR, Sweeney C, Andrews E, Conway TJ, Masarie K, Miller JB, Bruhwiler LMP, Pétron G, Hirsch I, Worthy DEJ, van der Werf GR, Randerson JT, Wennberg PO, Krol MC, Tans PP. 2007. An atmospheric perspective on North American carbon dioxide exchange: CarbonTracker. Proc Natl Acad Sci 104:18925-30.

Popper KR. 1968. The logic of scientific discovery. New York: Harper Torchbooks.

Pye JM 1988. Impact of ozone on the growth and yield of tress: a review. J Environ Qual 17:347-60.

Rastetter EB. 1996. Validating models of ecosystem response to global change. Bioscience 46:190-8.

Rastetter EB, Ågren GI, Shaver GR. 1997. Responses of N-limited ecosystems to increased $\mathrm{CO}_{2}$ : a balanced-nutrition, coupledelement-cycles model. Ecol Appl 7:444-60.

Ramankutty N, Gibbs HK, Achard F, DeFries R, Foley JA, Houghton RA. 2007. Challenges to estimating carbon emissions from tropical deforestation. Glob Change Biol 13:51-66.

Reay DS, Dentener F, Smith P, Grace J, Feely RA. 2008. Global nitrogen deposition and carbon sinks. Nat Geosci 430:1-7.

Ren W, Tian HQ, Chen GS, Liu ML, Zhang C, Chappelka A, Pan S. 2007a. Influence of ozone pollution and climate variability on grassland ecosystem productivity across China. Environ Pollut 149:327-35.

Ren W, Tian H, Liu M, Zhang C, Chen G, Pan S, Felzer B, Xu X. 2007b. Effects of tropospheric ozone pollution on net primary productivity and carbon storage in terrestrial ecosystems of China. J Geophys Res 1 12:D22S09. doi:10.1029/2007JD008521.

Ren W, Tian H, Tao B, Chappelka A, Sun G, Lu C, Liu M, Chen G, Xu X. 2011a. Impacts of tropospheric ozone and climate change on net primary productivity and net carbon exchange of China's forest ecosystems assessed with the dynamic land ecosystem model (DLEM). Glob Ecol Biogeogr 20:391-406.

Ren W, Tian HQ, Xu XF, Liu ML, Lu CQ, Chen GS, Mellio J, Reilly J, Liu JY. 2011 b. Spatial and temporal patterns of $\mathrm{CO}_{2}$ and $\mathrm{CH}_{4}$ fluxes in China's croplands in response to multifactor environmental changes. Tellus B 63:222-40.

Richardson AD, Anderson RS, Arain MA, other NACP Participants. 2012. Terrestrial biosphere models need better representation of vegetation phenology: results from the North American carbon program site synthesis. Glob Change Biol 18:566-84.

Ruddy BC, Lorenz DL, Mueller DK. 2006. County-level estimates of nutrient inputs to the land surface of the conterminous United States, 1982-2001. U.S. Geological Survey Scientific Investigations Report 2006-5012. http://pubs.usgs.gov/sir/2006/5012/.

Schimel D, House J, Hibbard K, Bousquet P, Ciais P, Peylin P, Apps M, Baker D, Bondeau A, Brasswell R, Canadell J, Churkina G, Cramer W, Denning S, Field C, Friedlingstein P, Goodale C, Heimann M, Houghton RA, Melillo J, Moore BIII, Murdiyarso D, Noble I, Pacala S, Prentice C, Raupach M, 
Rayner P, Scholes B, Steffen W, Wirth C. 2001. Recent patterns and mechanisms of carbon exchange by terrestrial ecosystems. Nature 414:169-72.

Schimel D, Melillo JM, Tian H, McGuire AD, Kicklighter DW, Kittel T, Rosenbloom N, Running SW, Thornton P, Ojima D, Parton W, Kelly R, Sykes M, Neilson R, Rizzo B. 2000. Contribution of increasing $\mathrm{CO}_{2}$ and climate to carbon storage by ecosystems in the United States. Science 287:2004-6.

Schwalm CR, Williams CA, Schaefer K, NACP participants. 2010. A model-data intercomparison of $\mathrm{CO}_{2}$ exchange across North America: results from the North American carbon program site synthesis. J Geophys Res 115:G00H05. doi:10.1029/ 2009JG001229.

Smith WB, Miles PD, Perry CH, Pugh SA. 2009. Forest Resources of the United States, 2007. General Technical Report WO-78. U.S. Department of Agriculture, Forest Service, Washington, DC

Sulman B, Desai A, Schroeder N, Ricciuto D, Barr A, Richardson A, Flanagan L, Lafleur P, Tian H, Chen G, Grant R, Poulter B, Verbeeck H, Ciais P, Ringeval B, Baker I, Schaefer K, Luo Y, Weng E. 2012. Impact of hydrological variations on modeling of peatland $\mathrm{CO}_{2}$ fluxes: results from the North American carbon program site synthesis. J Geophys Res. doi:10.1029/ 2011 JG001862.

Thenkabail PS, Biradar CM, Turral H, Noojipady P, Li YJ, Vithanage J, Dheeravath V, Velpuri M, Schull M, Cai XL, Dutta R. 2006. An irrigated area map of the world (1999) derived from remote sensing. Research Report 105, International Water Management Institute, Colombo, Sri Lanka.

Tian H, Melillo JM, Kicklighter DW, McGuire AD, Helfrich J. 1999. The sensitivity of terrestrial carbon storage to historical atmospheric $\mathrm{CO}_{2}$ and climate variability in the United States. Tellus 51B:414-52.

Tian H, Chen G, Liu M, Zhang C, Sun G, Lu C, Xu X, Ren W, Pan S, Chappelka A. 2010a. Model estimates of ecosystem net Primary productivity, evapotranspiration, and water use efficiency in the southern United States during 1895-2007. For Ecol Manag 259:1311-27.

Tian H, Xu X, Liu M, Ren W, Zhang C, Chen G, Lu C. 2010b. Spatial and temporal patterns of $\mathrm{CH}_{4}$ and $\mathrm{N}_{2} \mathrm{O}$ fluxes in terrestrial ecosystems of North America during 1979-2008: application of a global biogeochemistry model. Biogeosciences $7: 2673-94$.

Tian H, Xu X, Lu C, Liu M, Ren W, Chen G, Melillo J, Liu J. 201 la. Net exchanges of $\mathrm{CO}_{2}, \mathrm{CH}_{4}$, and $\mathrm{N}_{2} \mathrm{O}$ between China's terrestrial ecosystems and the atmosphere and their contributions to global climate warming. J Geophys Res G02011, doi:10.1029/2010JG001393.

Tian H, Melillo J, Lu C, Kicklighter D, Liu M, Ren W, Xu X, Chen G, Zhang C, Pan S, Liu J, Running S. 201 lb. China's terrestrial carbon balance: contribution of multiple global change factors. Global Biogeochemical Cycles 25, GB 1007, doi:10.1029/ 2010 GB003838.

Van Aardenne J, Dentener F, Olivier J, Goldewijk CK, Lelieveld J. 2001. A $1^{\circ} \times 1^{\circ}$ resolution data set of historical anthropogenic trace gas emissions for the period 1890-1990. Glob Biogeochem Cycles 15:909-28.

Wear DN. 2002. Land use. In: Wear DN, Greis JG, Eds. Southern forest resource assessment. pp. 153-174. Tech. Rep. GTR SRS53. USDA, Forest Service, Washington, DC. http://www.srs. fs.usda.gov/sustain/report/.

Woodwell GM, Mackenzie FT, Houghton RA, Apps MJ, Gorham E, Davidson EA. 1995. Will the warming speed the warming? In: Woodwell GM, MacKenzie FT, Eds. Biotic feedbacks in the global climatic system: will the warming feed the warming? Oxford: Oxford University Press. p 393-411.

Xu X, Tian H, Zhang C, Liu M, Ren W, Chen GS, Lu C, Bruhwiler L. 2010. Attribution of spatial and temporal variations in terrestrial methane flux over North America. Biogeosciences 7:3637-55.

Zhang C, Tian H, Chappelka A, Ren W, Chen H, Pan S, Liu M, Styers DM, Chen GS, Wang Y. 2007. Impacts of climatic and atmospheric changes on carbon dynamics in the Great Smoky Mountains. Environ Pollut 149:336-47.

Zhang C, Tian H, Wang Y, Zeng T, Liu Y. 2010. Predicting response of fuel load to future changes in climate and atmospheric composition in the southern United States. For Ecol Manag 260:556-64.

Zhang C, Tian H, Chen G, Chappelka A, Xu X, Ren W, Hui D, Liu M, Lu C, Pan S, Lockaby G. 2012. Impacts of urbanization on carbon balance of the Southern United States from 1945 to 2007. Environ Pollut 164:89-101. doi:10.1016/j.envpol.2012. 01.020 .

Zhao M, Running SW. 2010. Drought-induced reduction in global terrestrial net primary production from 2000 through 2009. Science 329:940-3.

Zhou XH, Weng ES, Luo YQ. 2008. Modeling patterns of nonlinearity in ecosystem responses to temperature, $\mathrm{CO} 2$, and precipitation changes. Ecol Appl 18:453-66. 